\title{
Development and application of bio-economic modelling to compare silvoarable, arable, and forestry systems in three European countries
}

\author{
A.R. Graves ${ }^{a, *}$, P.J. Burgess ${ }^{a}$, J.H.N. Palma ${ }^{b}$, F. Herzog ${ }^{b}$, G. Moreno ${ }^{c}$, M. Bertomeu ${ }^{c}$, \\ C. Dupraz ${ }^{d}$, F. Liagre ${ }^{e}$, K. Keesman ${ }^{f}$, W. van der Werff, A. Koeffeman de Nooy ${ }^{g}$, \\ J.P. van den Briel ${ }^{g}$ \\ a Natural Resources Management Institute, Cranfield University, Cranfield, UK \\ b Agroscope ART Reckenholz, Zürich, Switzerland \\ c Universidad de Extremadura, Centro Universitario de Plasencia, Plasencia, Spain \\ d Institut National de la Recherche Agronomique, Montpellier, France \\ e Assemblée Permanente des Chambres d'Agriculture, Paris, France \\ f Wageningen University, P.O. Box 43, 6700 AA Wageningen, The Netherlands \\ g Stafkantoor Gelders Particulier Grondbezit, Wageningen, The Netherlands
}

\section{A R T I C L E I N F O}

\section{Article history:}

Received 17 February 2005

Received in revised form

20 June 2006

Accepted 25 September 2006

\section{Keywords:}

Agroforestry

Silvoarable

Arable

Forestry

Modelling

Biophysical

Economics

Farm-SAFE

Yield-SAFE

Temperate

Walnut

Poplar

\begin{abstract}
A B S T R A C T
Silvoarable agroforestry could promote use of trees on farms in Europe, but its likely effect on production, farm profitability, and environmental services is poorly understood. Hence, from 2001 to 2005, the Silvoarable Agroforestry for Europe project developed a systematic process to evaluate the biophysical and economic performance of arable, forestry, and silvoarable systems in Spain, France, and The Netherlands. A biophysical model called "Yield-SAFE" was developed to predict long-term yields for the different systems and local statistics and expert opinion were used to derive their revenue, costs, and pre- and post-2005 grant regimes. These data were then used in an economic model called "Farm-SAFE" to predict plot- and farm-scale profitability. Land equivalent ratios were greater than one, showing Yield-SAFE predicted that growing trees and crops in silvoarable systems was more productive than growing them separately. Pre-2005 grants in Spain and The Netherlands penalised silvoarable systems, but post-2005 grants were more equitable. In France, walnut and poplar silvoarable systems were consistently the most profitable system under both grant regimes. In Spain, holm oak and stone pine silvoarable systems were the least profitable system under pre-2005 grants, but only marginally less profitable than arable systems under post-2005 grants. In The Netherlands, low timber values and the opportunity cost of losing arable land for slurry manure application made silvoarable and forestry systems uncompetitive with arable systems under both grant regimes.
\end{abstract}

(c) 2006 Elsevier B.V. All rights reserved.

\footnotetext{
* Corresponding author. Tel.: +44 1234 750111x2727; fax: +44 1234752971.

E-mail address: a.r.graves@cranfield.ac.uk (A.R. Graves). 
Wild cherry

Oak

Stone pine

France

Spain

The Netherlands

\section{Introduction}

Agroforestry is a form of multi-cropping, involving at least one woody-perennial species, and ecological and economic interactions between the components. Agroforestry systems can be described by their components (crops, animals, and trees) and their spatial (dispersed or zoned) and temporal (coincident to sequential) arrangement (Nair, 1985; Sinclair, 1999). Silvoarable agroforestry is defined as the practice of growing an arable crop between spatially zoned trees (Dupraz and Newman, 1997; Burgess et al., 2004b).

Most research on agroforestry systems has evaluated their biophysical performance despite the observation that it is often socio-economic constraints that limit their adoption (Graves et al., 2004; Mercer et al., 1998). In practice, because of biophysical and socio-economic interactions (Dyack et al., 1999), there is a need to consider both of these together. However, complete empirical data for entire tree rotations are rare and computer simulations therefore provide a means of systematically undertaking biophysical and economic analyses of silvoarable systems in the absence of such data.

Various biophysical and economic models have been developed for monocultures of arable and forestry systems, but relatively few have been developed for silvoarable agroforestry (Graves et al., 2005a). Current bio-economic models of silvoarable agroforestry range from detailed biophysical models with limited economic analysis to economic models that use biophysical data from an external source (Graves et al., 2005a). Bio-economic modelling has been used to examine profitability (Thomas, 1991; Willis et al., 1993; Thomas and Willis, 1997; Burgess et al., 2000) and feasibility (Dupraz et al., 1995) of silvoarable agroforestry in Europe. Profitability is usually assessed at a plot-scale (1 ha) and performance is compared with that in competing systems, such as arable and forestry systems. Feasibility is usually determined at a farmscale to view how silvoarable agroforestry affects cash-flow and resource use. This paper describes the integrated use of a biophysical and an economic model, at both a plot- (1 ha) and farm-scale, to determine the profitability of silvoarable systems in comparison with arable and forestry systems. In particular, it describes the effect of grants on the profitability of silvoarable systems relative to that of arable and forestry systems. The study focuses on three countries, Spain, France, and The Netherlands, selected because of their differing climates, tree and crop species, and grant regimes.

\section{Method}

In order to determine the profitability of arable, forestry, and silvoarable systems, a method comprising five steps was used.
These included: (1) identifying and characterising potential sites for the uptake of silvoarable agroforestry, (2) defining potential arable, forestry and silvoarable systems for those sites, (3) using a bio-physical model to determine yields for those systems, (4) defining the revenue, costs and grant regimes associated with each site, and (5) using an economic model to determine the financial effects at a plot- and farmscale.

\subsection{Identification and characterisation of landscape test sites}

Since a major objective was to determine if silvoarable agroforestry could provide a profitable alternative land use in areas dominated by arable cropping, potential sites were limited to areas where there was arable land, as specified by the PanEuropean Land Cover Monitoring (PELCOM) project (Mücher, 2000). The sites were also restricted to those areas belonging to the three dominant environmental classes in each country (or one in the case of The Netherlands), as described by Mücher et al. (2003) in a statistical analysis of climate and topography. Within these constraints, three landscape test sites, measuring $4 \mathrm{~km} \times 4 \mathrm{~km}$, from each environmental class, were randomly selected using a geographical information systems, to give nine, nine, and three landscape test sites in Spain, France and The Netherlands, respectively. Two sites in France were later discarded for lack of associated data, giving 19 sites altogether (Table 1).

To provide input data for the biophysical model, daily mean values of air temperature, total short-wave radiation, and rainfall were generated for each landscape test site using CLIGEN 5.2 (United States Department of Agriculture, 2005) with reference values from the nearest weather station (Global Data Systems, 2005). The annual values for mean air temperature and total radiation were highest in Spain (9.1-15.5 ${ }^{\circ} \mathrm{C}$ and $\left.5480-6600 \mathrm{MJ} \mathrm{m}^{-2}\right)$ and lowest in The Netherlands $\left(8.8-9.0^{\circ} \mathrm{C}\right.$ and $3690-4830 \mathrm{MJ} \mathrm{m}^{-2}$ ) (Table 1). Mean annual rainfall was lowest in spain $(320-530 \mathrm{~mm})$ and highest in France (590-1080 mm). In Spain, much of the rainfall occurred in winter, with minimal rainfall in summer. In France, seasonality of rainfall, although greatly reduced, was still evident, while in The Netherlands, rainfall was generally consistent throughout the year.

Soil depth and texture were defined for each landscape test site, and using a classification of hydraulic properties of European soils (Wösten et al., 1999), available soil water content was described using van Genuchten's equation (1980). Further data layers for elevation and land cover were developed, and the effect of topography on relative radiation was calculated from digital elevation models in the Digitales Gelände-Modell (DiGeM@) (Conrad, 2002). Field visits were also made to each 
Table 1 - Summary of the latitude, longitude, altitude, mean air temperature, annual solar radiation receipt and annual rainfall at each site

\begin{tabular}{|c|c|c|c|c|c|c|c|}
\hline Country and region & Site name & Latitude & Longitude & $\begin{array}{l}\text { Altitude } \\
\text { (m) }\end{array}$ & $\begin{array}{c}\text { Mean } \\
\text { temperature } \\
\left({ }^{\circ} \mathrm{C}\right)\end{array}$ & $\begin{array}{l}\text { Solar } \\
\text { radiation } \\
\left(\mathrm{MJ} \mathrm{m}^{-2}\right)\end{array}$ & $\begin{array}{c}\text { Annual } \\
\text { rainfall } \\
\text { (mm) }\end{array}$ \\
\hline \multicolumn{8}{|l|}{ Spain } \\
\hline \multirow[t]{2}{*}{ Andalucia } & Alcala la real & $37^{\circ} 36^{\prime} \mathrm{N}$ & $3^{\circ} 88^{\prime} \mathrm{W}$ & 1000 & 15.3 & 5490 & 355 \\
\hline & Torrijos & $39^{\circ} 89^{\prime} \mathrm{N}$ & $4^{\circ} 39^{\prime} \mathrm{W}$ & 500 & 15.5 & 5560 & 348 \\
\hline \multirow[t]{4}{*}{ Castilla La Mancha } & Ocaña & $39^{\circ} 94^{\prime} \mathrm{N}$ & $3^{\circ} 44^{\prime} \mathrm{W}$ & 700 & 14.7 & 5780 & 316 \\
\hline & Almonacid de Zorita & $40^{\circ} 23^{\prime} \mathrm{N}$ & $2^{\circ} 61^{\prime} \mathrm{W}$ & 900 & 12.6 & 6610 & 404 \\
\hline & Cardenosa El Espinar & $40^{\circ} 78^{\prime} \mathrm{N}$ & $4^{\circ} 53^{\prime} \mathrm{W}$ & 1000 & 12.0 & 5700 & 404 \\
\hline & Fontiveros & $40^{\circ} 86^{\prime} \mathrm{N}$ & $5^{\circ} 00^{\prime} \mathrm{W}$ & 900 & 12.0 & 6170 & 393 \\
\hline \multirow[t]{3}{*}{ Castilla y Leon } & Olmedo & $41^{\circ} 28^{\prime} \mathrm{N}$ & $4^{\circ} 80^{\prime} \mathrm{W}$ & 750 & 12.5 & 5480 & 410 \\
\hline & St Maria del Campo & $42^{\circ} 11^{\prime} \mathrm{N}$ & $3^{\circ} 91^{\prime} \mathrm{W}$ & 800 & 9.1 & 5630 & 530 \\
\hline & St Maria del Paramo & $42^{\circ} 44^{\prime} \mathrm{N}$ & $5^{\circ} 69^{\prime} \mathrm{W}$ & 800 & 10.2 & 6600 & 519 \\
\hline \multicolumn{8}{|l|}{ France } \\
\hline \multirow[t]{2}{*}{ Poitou Charentes } & Champdeniers & $46^{\circ} 41^{\prime} \mathrm{N}$ & $0^{\circ} 02^{\prime} \mathrm{E}$ & 200 & 11.0 & 4740 & 648 \\
\hline & Chateauroux & $46^{\circ} 92^{\prime} \mathrm{N}$ & $1^{\circ} 65^{\prime} \mathrm{E}$ & 150 & 11.0 & 4750 & 587 \\
\hline \multirow[t]{2}{*}{ Centre } & Fussy & $47^{\circ} 18^{\prime} \mathrm{N}$ & $2^{\circ} 47^{\prime} \mathrm{E}$ & 200 & 10.6 & 4800 & 626 \\
\hline & Sancerre & $47^{\circ} 30^{\prime} \mathrm{N}$ & $2^{\circ} 72^{\prime} \mathrm{E}$ & 400 & 10.7 & 4590 & 724 \\
\hline \multirow[t]{3}{*}{ Franche Comté } & Champlitte & $47^{\circ} 64^{\prime} \mathrm{N}$ & $5^{\circ} 58^{\prime} \mathrm{E}$ & 300 & 8.5 & 4940 & 773 \\
\hline & Dampierre & $47^{\circ} 61^{\prime} \mathrm{N}$ & $5^{\circ} 82^{\prime} \mathrm{E}$ & 300 & 10.0 & 5090 & 1072 \\
\hline & Vitrey & $47^{\circ} 81^{\prime} \mathrm{N}$ & $5^{\circ} 78^{\prime} \mathrm{E}$ & 400 & 9.5 & 4900 & 1084 \\
\hline \multicolumn{8}{|l|}{ The Netherlands } \\
\hline & Bentelo & $52^{\circ} 22^{\prime} \mathrm{N}$ & $6^{\circ} 67^{\prime} \mathrm{E}$ & 0 & 8.8 & 3690 & 729 \\
\hline & Balkbrug & $52^{\circ} 57^{\prime} \mathrm{N}$ & $6^{\circ} 34^{\prime} \mathrm{E}$ & 0 & 8.9 & 4830 & 818 \\
\hline & Scherpenzeel & $52^{\circ} 57^{\prime} \mathrm{N}$ & $6^{\circ} 34^{\prime} \mathrm{E}$ & 0 & 9.0 & 3710 & 801 \\
\hline
\end{tabular}

site to confirm existing interpretation, improve existing data, and provide missing data.

To provide a qualitative description of the arable land in each landscape test site, between one and four "land units" were defined, by excluding non-arable land and then using a cluster analysis of available soil water content and relative solar radiation receipt on the remaining area (Table 2). In total, there were 42 land units.

\subsection{Definition of tree and crop species and management}

The land units defined for each landscape test site were ranked according to their quality, and expert opinion was used to determine the most suitable tree species and crop rotation for each land unit. In Spain, the trees selected were holm oak (Quercus ilex) and stone pine (Pinus pinea), in France, wild cherry (Prunus avium), walnut (Juglans spp.), and poplar (Populus spp.) and in The Netherlands, walnut and poplar. In Spain, arable systems were based on wheat, sunflower, and fallow. In France, arable systems at Champdeniers, Chateauroux, Fussy, and Sancerre were based on wheat and sunflower and, in the Franche Comté region (Champlitte, Fussy and Vitrey) on wheat, oilseed (Brassica napus) and grain maize. In The Netherlands, wheat and forage maize were assumed for the arable systems. The silvoarable systems integrated the forestry tree species and arable crop species and rotation for each land unit.
The management of the arable systems reflected local practice. Management of the forestry systems was also based on local practice. In Spain, planting densities, thinning, and pruning for oak were derived from Pulido et al. (2003), and for stone pine, from Yagüe (1994) and Montero and Cañella (2000). In France, management for forestry systems was developed using the Institut pour le Développement Forestier (1997), Souleres (1992), Boulet-Gercourt (1997) and the Centre Régional de la Propriété Forestière (1997). In The Netherlands, the receipt of grants was conditional on an appropriate planting density (Ministerie van Landbouw, Natuur en Voedselkwaliteit, 2004). In each country, it was assumed that each tree species was planted in year 1 and that holm oak, stone pine, wild cherry, and walnut were "harvested" to provide revenue in year 60 . In the case of poplar, a rotation of 20 years was assumed with re-planting in years 21 and 41. Management of the silvoarable systems combined the management of the arable and forestry systems, using expert judgement as appropriate.

\subsection{Biophysical modelling}

The tree and crop yields for the selected arable, forestry, and silvoarable systems were modelled using Yield-SAFE (Van der Werf et al., 2007). A default set of parameters for the "potential" yield of each tree and crop species (Van Ittersum and Rabbinge, 1997) was developed, assuming no water limita- 
Table 2 - The total utilised agricultural area for each hypothetical farm and description of the 42 different land units, and the selected tree and crop species

\begin{tabular}{|c|c|c|c|c|c|c|c|}
\hline Country & Land unit & Area (ha) & $\begin{array}{l}\text { Radiation } \\
(\%)\end{array}$ & $\begin{array}{l}\text { Soil } \\
\text { texture }\end{array}$ & $\begin{array}{l}\text { Soil depth } \\
\quad(\mathrm{cm})\end{array}$ & Tree & Crop rotation \\
\hline \multirow[t]{19}{*}{ Spain } & Alcala 1 & 58 & 97 & M & 140 & Oak & $\mathrm{w} / \mathrm{w} / \mathrm{f}$ \\
\hline & Alcala 2 & 15 & 86 & M & 50 & Oak & $\mathrm{w} / \mathrm{w} / \mathrm{f}$ \\
\hline & Torrijos 1 & 10 & 101 & M & 140 & Oak & $\mathrm{w} / \mathrm{f}$ \\
\hline & Torrijos 2 & 56 & 100 & M & 140 & Oak & $\mathrm{w} / \mathrm{w} / \mathrm{f}$ \\
\hline & Ocaña & 66 & 100 & M & 140 & Oak & $\mathrm{w} / \mathrm{w} / \mathrm{f}$ \\
\hline & Almonacid 1 & 59 & 97 & M & 140 & Oak & $\mathrm{w} / \mathrm{f}$ \\
\hline & Almonacid 2 & 7 & 83 & $\mathrm{~F}$ & 140 & Oak & $\mathrm{s} / \mathrm{s} / \mathrm{s} / \mathrm{s} / \mathrm{s} / \mathrm{w} / \mathrm{f}$ \\
\hline & Cardenosa 1 & 23 & 93 & M & 140 & Oak & $\mathrm{w} / \mathrm{w} / \mathrm{w} / \mathrm{f}$ \\
\hline & Cardenosa 2 & 35 & 101 & $\mathrm{~F}$ & 140 & Oak & $\mathrm{w} / \mathrm{w} / \mathrm{w} / \mathrm{f}$ \\
\hline & Fontiveros 1 & 49 & 99 & C & 140 & Oak & $\mathrm{w} / \mathrm{w} / \mathrm{w} / \mathrm{w} / \mathrm{f}$ \\
\hline & Fontiveros 2 & 9 & 98 & C & 140 & Pine & $\mathrm{w} / \mathrm{w} / \mathrm{w} / \mathrm{w} / \mathrm{f}$ \\
\hline & Olmedo 1 & 5 & 100 & C & 140 & Pine & $\mathrm{w} / \mathrm{s} / \mathrm{f}$ \\
\hline & Olmedo 2 & 34 & 100 & M & 140 & Oak & $\mathrm{w} / \mathrm{s} / \mathrm{f}$ \\
\hline & Olmedo 3 & 18 & 99 & C & 140 & Oak & $\mathrm{w} / \mathrm{s} / \mathrm{f}$ \\
\hline & Campo 1 & 44 & 99 & C & 140 & Pine & $\mathrm{w} / \mathrm{w} / \mathrm{w} / \mathrm{f}$ \\
\hline & Campo 2 & 14 & 99 & M & 140 & Oak & $\mathrm{w} / \mathrm{w} / \mathrm{w} / \mathrm{w} / \mathrm{w} / \mathrm{f}$ \\
\hline & Paramo 1 & 4 & 100 & $\mathrm{M}$ & 140 & Oak & $\mathrm{w} / \mathrm{w} / \mathrm{w} / \mathrm{s} / \mathrm{f}$ \\
\hline & Paramo 2 & 34 & 100 & M & 140 & Oak & $\mathrm{w} / \mathrm{w} / \mathrm{w} / \mathrm{s} / \mathrm{f}$ \\
\hline & Paramo 3 & 21 & 101 & M & 140 & Oak & $\mathrm{w} / \mathrm{w} / \mathrm{w} / \mathrm{s} / \mathrm{f}$ \\
\hline \multirow[t]{20}{*}{ France } & Champdeniers 1 & 67 & 100 & $\mathrm{~F}$ & 80 & Cherry & $\mathrm{w} / \mathrm{w} / \mathrm{s} / \mathrm{w} / \mathrm{o} / \mathrm{s}$ \\
\hline & Champdeniers 2 & 27 & 100 & M & 120 & Walnut & $\mathrm{w} / \mathrm{w} / \mathrm{s} / \mathrm{w} / \mathrm{o} / \mathrm{s}$ \\
\hline & Chateauroux 1 & 32 & 102 & $\mathrm{~F}$ & 80 & Walnut & $\mathrm{w} / \mathrm{w} / \mathrm{o} / \mathrm{w} / \mathrm{o} / \mathrm{s}$ \\
\hline & Chateauroux 3 & 86 & 102 & M & 120 & Walnut & w/w/o \\
\hline & Chateauroux 2 & 23 & 102 & $\mathrm{~F}$ & 40 & Cherry & w/w/o/w/o/s \\
\hline & Chateauroux 4 & 11 & 100 & $\mathrm{~F}$ & 40 & Cherry & $\mathrm{w} / \mathrm{w} / \mathrm{o} / \mathrm{w} / \mathrm{o} / \mathrm{s}$ \\
\hline & Fussy 1 & 10 & 101 & $\mathrm{~F}$ & 40 & Cherry & w/o \\
\hline & Fussy 2 & 43 & 103 & M & 80 & Poplar & $\mathrm{w} / \mathrm{w} / \mathrm{o}$ \\
\hline & Fussy 3 & 27 & 102 & $\mathrm{~F}$ & 120 & Cherry & w/o \\
\hline & Sancerre 1 & 37 & 103 & $\mathrm{~F}$ & 40 & Cherry & $\mathrm{o} / \mathrm{w} / \mathrm{s} / \mathrm{w} / \mathrm{w} / \mathrm{w} / \mathrm{o}$ \\
\hline & Sancerre 3 & 44 & 101 & Vf & 120 & Cherry & $\mathrm{o} / \mathrm{w} / \mathrm{s} / \mathrm{w} / \mathrm{w} / \mathrm{w} / \mathrm{o}$ \\
\hline & Sancerre 4 & 7 & 100 & $\mathrm{C}$ & 80 & Cherry & $\mathrm{o} / \mathrm{w} / \mathrm{s} / \mathrm{w}$ \\
\hline & Sancerre 2 & 10 & 102 & Vf & 140 & Poplar & $\mathrm{o} / \mathrm{w} / \mathrm{s} / \mathrm{w} / \mathrm{w} / \mathrm{w} / \mathrm{o}$ \\
\hline & Champlitte 1 & 68 & 103 & M & 140 & Cherry & w/w/o \\
\hline & Champlitte 2 & 62 & 103 & $M-f$ & 35 & Walnut & $\mathrm{w} / \mathrm{w} / \mathrm{w} / \mathrm{w} / \mathrm{w} / \mathrm{gm}$ \\
\hline & Dampierre 1 & 64 & 98 & M & 140 & Cherry & $\mathrm{w} / \mathrm{w} / \mathrm{gm}$ \\
\hline & Dampierre 2 & 43 & 97 & $\mathrm{~F}$ & 35 & Cherry & $\mathrm{w} / \mathrm{w} / \mathrm{w} / \mathrm{gm}$ \\
\hline & Dampierre 3 & 23 & 95 & Mf & 60 & Poplar & $\mathrm{w} / \mathrm{gm}$ \\
\hline & Vitrey 1 & 46 & 103 & M & 60 & Cherry & w/w/o \\
\hline & Vitrey 2 & 74 & 103 & Mf & 60 & Poplar & $\mathrm{w} / \mathrm{w} / \mathrm{gm}$ \\
\hline \multirow[t]{3}{*}{ The Netherlands } & Bentelo 1 & 40 & 100 & C & 140 & Walnut & $\mathrm{w} / \mathrm{w} / \mathrm{fm}$ \\
\hline & Balkbrugg 1 & 40 & 100 & C & 140 & Poplar & $\mathrm{fm}$ \\
\hline & Scherpenzeel 1 & 10 & 100 & C & 140 & Poplar & $\mathrm{fm}$ \\
\hline
\end{tabular}

Note: soil texture - C: coarse; M: medium; M-f: medium-fine, F: fine; V-f: very fine; crop type - w: wheat; f: fallow; o: oilseed; s: sunflower; gm: grain maize; fm: forage maize.

tion on growth (Burgess et al., 2004a). These parameters were then used to determine water limited "reference" yields for the forestry and arable systems by adjusting three parameters (harvest index, water use efficiency and a management factor) within acceptable boundaries, so that predicted Yield-SAFE yields matched reference yields. Local crop and tree management, and radiation, rainfall, temperature, and soil depth data for each landscape test site were used as inputs for Yield-SAFE. Dry wood densities assumed for timber ranged from $410 \mathrm{~kg} \mathrm{~m}^{-3}$ for poplar to $900 \mathrm{~kg} \mathrm{~m}^{-3}$ for oak; intermediate values of 570 to $608 \mathrm{~kg} \mathrm{~m}^{-3}$ were used for walnut, stone pine, and wild cherry. The reference yields for each crop and tree species were determined from national statistics and expert opinion, during workshops in each country.

Using the parameter set developed for reference yields and soils at each landscape test site, tree and crop yields for each land unit were predicted for monoculture forestry and arable systems and two silvoarable systems of 50 or 113 trees ha ${ }^{-1}$. From the biophysical yields, it was possible to estimate a land equivalent ratio (LER) for each system. Land equivalent ratios were initially defined for mixed cropping systems (Mead and Willey, 1980) and have been adapted for agroforestry systems (Ong, 1996; Dupraz, 1998). The land equivalent ratio is "the ratio of the area under sole cropping to the area under the agroforestry system, at the same level of management that 
gives an equal amount of yield" (Ong, 1996) and is expressed as

$\mathrm{LER}=\frac{\text { Tree silvoarable yield }}{\text { Tree monoculture yield }}+\frac{\text { Crop silvoarable yield }}{\text { Crop monoculture yield }}$

Where more than one crop occurred in the rotation, a weighted ratio for each crop was used, depending on its proportion in the rotation.

\subsection{Definition of revenue, costs, and grants}

Financial data on the revenue and costs associated with arable, forestry, and silvoarable systems were collected on electronic templates for each landscape test site, using local and national statistics, and expert opinion (Graves, 2005). For the crop component of the silvoarable system, the variable and assignable fixed costs were applied according to the proportion of the arable area in the system. It was also assumed that cropping would only continue if the intercrop net margin (calculated on a 5 year moving average to remove the effect of yield variation) was profitable, after which it was assumed the intercrop area would be fallowed.

The financial data for forestry and the tree component of the silvoarable system comprised the revenue from timber and subsidies, and the costs of woodland establishment and management. The revenue from timber was calculated using relationships between the standing value of a cubic metre of timber and the timber volume for each species in each country. The costs associated with the forestry system and the tree component of the silvoarable systems were based on various sources.

A particular focus of this study was the effect of grants, and three regimes were examined: a zero grant regime, a pre2005 grant regime, associated with direct area payments, and a post-2005 grant regime associated with the single farm payment scheme. The pre- and post-2005 grant regimes for arable, forestry, and silvoarable systems was established from local, national, and European documents (European Commission, 2004), and expert opinion. However, since the post-2005 grant regime for silvoarable agroforestry was unclear, two extreme scenarios were developed. In scenario 1, the single farm payment was assumed for the percentage of cropped area in the system, without tree payments. In scenario 2, the single farm payment was assumed for the whole system, with a planting grant to cover $50 \%$ of the tree costs in the first 4 years of the tree rotation.

\subsection{Plot-scale economic modelling}

The predicted annual yields of trees and crops were used as inputs for a plot- and farm-scale cost-benefit economic model called "Farm-SAFE" (Graves et al., 2005b).

In arable systems, profitability is typically compared on an annual and per unit area basis by adding the revenue generated $(R)$ to the variable costs associated with generating that revenue $(V)$ to give a gross margin (gross margin $=R-V$ ) (Ministry of Agriculture, Fisheries and Food, 1983). However, because other costs such as labour and machinery, sometimes termed "assignable fixed costs" (A), are modifiable over a long time period, it is common practice to compare arable, forestry, and silvoarable systems on the basis of their net margin (net margin $=\mathrm{R}-\mathrm{V}-\mathrm{A}$ ) (Willis et al., 1993; Burgess et al., 2000; Graves et al., 2005b). As the benefits and costs associated with tree-based systems occur over many years, discounted cost benefit analysis was used to define the present value of future costs and benefits from the arable, forestry, and silvoarable systems, using the approach first defined by Faustmann (1849). The net present value (NPV; units: $€ \mathrm{ha}^{-1}$ ) was expressed as

$\mathrm{NPV}=\sum_{t=0}^{t=T} \frac{R_{t}-V_{t}-A_{t}}{(1+i)^{t}}$

where NPV was the net present value of the arable, forestry, or silvoarable enterprise $\left(€ \mathrm{ha}^{-1}\right), R_{\mathrm{t}}$ the revenue from the enterprise (including subsidies) in year $t\left(€ \mathrm{ha}^{-1}\right), \mathrm{V}_{\mathrm{t}}$ the variable costs in year $t\left(€ \mathrm{ha}^{-1}\right), \mathrm{A}_{\mathrm{t}}$ the assignable fixed costs in year $\mathrm{t}\left(€ \mathrm{ha}^{-1}\right), \mathrm{T}$ the time horizon (years), and $\mathrm{i}$ was the discount rate (discount rate $=4 \%$ ).

In order to compare systems with different rotation lengths, an infinite net present value was calculated. This was the net present value defined over an infinite rotation, in which each replication had a rotation of $n$ years. The infinite net present value (iNPV; units: $€ \mathrm{ha}^{-1}$ ) was defined as

$i N P V=N P V \frac{(1+i)^{n}}{(1+i)^{n}-1}$

The infinite net present value was also expressed as an equivalent annual value (EAV) using the following formula

$\mathrm{EAV}=i \mathrm{NPV} \times i$

The zero, pre- and post-2005 grant regimes were examined in terms of their effect on the economic performance of the arable, forestry, and the silvoarable systems (113 trees ha ${ }^{-1}$ only) using the equivalent annual value (discount rate $=4 \%$ ).

\subsection{Farm-scale modelling}

In order to assess the feasibility of the selected silvoarable systems at a farm-scale, hypothetical cereal farms in each landscape test site were determined from regional data. In Spain, this was obtained from the Farm Accountancy Data Network (FADN) (European Commission, 2005), in The Netherlands, from the Agricultural Economics Research Institute (2005), and in France, from the Réseau d'observation des systèmes d'exploitation (ROSACE) (Assemblée Permanente des Chambres d'Agriculture, 2005). Where hypothetical cereal farms could not be determined from the available data, hypothetical farms were defined using the most commonly occurring farm type in the region. For each landscape test site, the area of each land unit relative to the total area of the land units was used to represent the proportion of each land unit within the hypothetical farms.

The Farm-SAFE model was used to determine the effect of up to four arable, four forestry, and four silvoarable systems on the financial resources of each farm. Economic feasibility at the farm-scale was determined using the infinite net present 
value of the farm $\left(\mathrm{iNPV}_{\text {farm }}\right.$; units: $€$ farm $\left.^{-1}\right)$. This aggregated net present values of the different systems and the net present value of "farm fixed costs" ( $F_{t}$ : units: $€$ farm $^{-1}$ ) over the same period of time, and was defined as

$$
\begin{aligned}
\mathrm{iNPV}_{\text {farm }}= & \left(\sum_{l=1}^{l=4} \operatorname{NPV}_{\mathrm{a}} a_{\mathrm{a}}+\mathrm{NPV}_{\mathrm{f}} a_{\mathrm{f}}+\mathrm{NPV}_{\mathrm{s}} a_{\mathrm{s}}-\sum_{\mathrm{t}=0}^{\mathrm{t}=\mathrm{T}} \frac{F_{\mathrm{t}}}{(1+i)^{\mathrm{t}}}\right) \\
& \times \frac{(1+i)^{n}}{(1+i)^{n}-1}
\end{aligned}
$$

where $l$ was one of the four possible land units, $N V_{a}, N V_{f}$, and $\mathrm{NPV}_{\mathrm{S}}$ the net present values $\left(€ \mathrm{ha}^{-1}\right.$ ) of arable, forestry and silvoarable enterprises in each unit $l, a_{\mathrm{a}}, a_{\mathrm{f}}$, and, $a_{\mathrm{s}}$ the area (ha) of arable, forestry, and silvoarable systems in each unit $l, F_{t}$ the farm fixed cost in year $t\left(€\right.$ farm $\left.^{-1}\right)$, $T$ the time horizon (years), $i$ the discount rate and $n$ was the duration of the rotation (years).

The infinite net present value of the farm was used to evaluate the economic effect of planting $10 \%$ of the farm with forestry or silvoarable systems, in comparison with the arable status quo of the hypothetical farms at each landscape test site, under the pre- and post-2005 grant regimes.

\section{Results}

\subsection{Yields in arable and forestry systems}

In Spain, the reference timber volumes for oak and stone pine in year 60 were assumed to be $0.22-0.26 \mathrm{~m}^{3}$ tree $^{-1}$,

\begin{tabular}{|c|c|c|c|c|c|c|}
\hline Country & Arable crop & $\begin{array}{l}\text { No. of } \\
\text { values }\end{array}$ & $\begin{array}{l}\text { Mean } \\
\left(\text { tha }^{-1}\right)\end{array}$ & $\begin{array}{l}\text { Standard deviation } \\
\left(\mathrm{tha}^{-1}\right)\end{array}$ & Range (tha ${ }^{-1}$ ) & $\begin{array}{l}\text { Coefficient of } \\
\text { variation (\%) }\end{array}$ \\
\hline \multirow[t]{2}{*}{ Spain } & Sunflower & 120 & 0.8 & 0.4 & $0.2-1.7$ & 52 \\
\hline & Wheat & 697 & 2.5 & 1.0 & $0.6-5.8$ & 40 \\
\hline \multirow[t]{4}{*}{ France } & Grain maize & 61 & 6.3 & 1.2 & $2.9-9.8$ & 20 \\
\hline & Oilseed & 260 & 3.2 & 0.4 & $1.9-4.3$ & 13 \\
\hline & Sunflower & 106 & 1.7 & 0.4 & $0.7-2.6$ & 26 \\
\hline & Wheat & 613 & 5.5 & 1.5 & $0.9-10.5$ & 27 \\
\hline \multirow[t]{2}{*}{ The Netherlands } & Forage maize & 80 & 11.5 & 1.7 & $8.0-15.9$ & 15 \\
\hline & Wheat & 20 & 7.9 & 1.2 & 5.9-11.1 & 16 \\
\hline Country & Tree species & $\begin{array}{l}\text { No. of } \\
\text { values }\end{array}$ & $\begin{array}{c}\text { Mean } \\
\left(\mathrm{m}^{3} \mathrm{ha}^{-1}\right)\end{array}$ & $\begin{array}{l}\text { Standard deviation } \\
\qquad\left(\mathrm{m}^{3} \mathrm{ha}^{-1}\right)\end{array}$ & Range $\left(\mathrm{m}^{3} \mathrm{ha}^{-1}\right)$ & $\begin{array}{l}\text { Coefficient of } \\
\text { variation (\%) }\end{array}$ \\
\hline \multirow[t]{2}{*}{ Spain } & Oak (60) & 16 & 0.33 & 0.050 & $0.23-0.43$ & 15 \\
\hline & Pine (60) & 3 & 0.25 & 0.005 & $0.25-0.26$ & 2 \\
\hline \multirow[t]{3}{*}{ France } & Cherry (60) & 12 & 0.88 & 0.151 & $0.71-1.15$ & 17 \\
\hline & Poplar (60) & 4 & 1.34 & 0.143 & $1.26-1.59$ & 11 \\
\hline & Walnut (60) & 4 & 1.01 & 0.008 & $1.00-1.02$ & 1 \\
\hline \multirow[t]{2}{*}{ The Netherlands } & Poplar (20) & 2 & 1.28 & 0.215 & $1.06-1.49$ & 17 \\
\hline & Walnut (60) & 1 & 0.71 & $\mathrm{n} / \mathrm{a}$ & 0.71 & $\mathrm{n} / \mathrm{a}$ \\
\hline
\end{tabular}
indicating relatively slow growth. In France, wild cherry

Note: values in brackets show length of rotation.

Table 4 - Relationship between (a) predicted crop yield and (b) predicted timber volume and soil depth for selected crop

\begin{tabular}{|c|c|c|c|c|c|}
\hline Country & $\begin{array}{c}\text { Crop or tree } \\
\text { species }\end{array}$ & No. of pairs & $\begin{array}{l}\text { Linear regression of crop yield } \\
\left(\mathrm{t} \mathrm{ha}^{-1}\right) \text { or timber volume } \\
\left(\mathrm{m}^{3} \mathrm{ha}^{-1}\right) \text { against depth, } d(\mathrm{~m})\end{array}$ & $\begin{array}{c}\text { Correlation } \\
\text { coefficient }\end{array}$ & $\begin{array}{l}\text { Significant } \\
(P=0.05)\end{array}$ \\
\hline Spain & Wheat & 697 & $2.34( \pm 1.02)+0.19 d$ & 0.02 & No \\
\hline \multirow[t]{4}{*}{ France } & Wheat & 613 & $3.69( \pm 1.23)+2.15 d$ & 0.57 & Yes \\
\hline & Grain maize & 61 & $4.90( \pm 0.92)+1.82 d$ & 0.67 & Yes \\
\hline & Sunflower & 106 & $1.06( \pm 0.39)+0.72 d$ & 0.49 & Yes \\
\hline & Oilseed & 260 & $2.95( \pm 0.42)+0.32 d$ & 0.26 & Yes \\
\hline Spain & Oak & 16 & $0.17( \pm 0.04)+0.12 d$ & 0.53 & No \\
\hline \multirow[t]{3}{*}{ France } & Cherry & 12 & $0.64( \pm 0.10)+0.29 d$ & 0.75 & Yes \\
\hline & Walnut & 4 & $1.02( \pm 0.01)+0.0028 d$ & -0.12 & No \\
\hline & Poplar & 4 & $0.98( \pm 0.04)+0.42 d$ & 0.97 & No \\
\hline
\end{tabular}
and tree species in Spain and France 
(1.04-1.06 $\mathrm{m}^{3}$ tree $\left.{ }^{-1}\right)$ and walnut $\left(1.04 \mathrm{~m}^{3}\right.$ tree $\left.{ }^{-1}\right)$ yields in year 60 were relatively high, indicating relatively fast-growing trees. Poplar was the fastest growing tree with reference yields of $1.46-1.51 \mathrm{~m}^{3}$ tree $^{-1}$ in year 20. In Spain, the reference yields for wheat were relatively low (1.62-3.71 tha ${ }^{-1}$ ) compared to those in France (6.5-8.0 tha ${ }^{-1}$ ) and The Netherlands $\left(7.8 \mathrm{tha}^{-1}\right)$. Reference sunflower yields were also lower in Spain (0.60-1.09 tha $\left.{ }^{-1}\right)$ than in France (2.3-2.5 tha $\left.{ }^{-1}\right)$. Reference yields for oilseed (3.2-4.0 tha ${ }^{-1}$ ) and grain maize (7.5-8.0 tha ${ }^{-1}$ ) were assumed only for France and a reference yield for forage maize (12 tha $\left.{ }^{-1}\right)$ assumed only for The Netherlands.

Crop yields developed using Yield-SAFE showed interannual variation around the reference values for each site, due to the inter-annual variation in temperature, rainfall, and solar radiation. Crop yields ranged from $0.2 \mathrm{tha}^{-1}$ for sunflower in Spain to 15.9 tha $^{-1}$ for maize in The Netherlands (Table 3). Although the greatest absolute variation in yield was associated with high yielding crops in The Netherlands and France, the relative variation in yields was greatest in Spain. For the

Land unit 2, St Maria del Campo, Spain (oak; wheat/wheat/wheat/wheat/wheat/fallow)
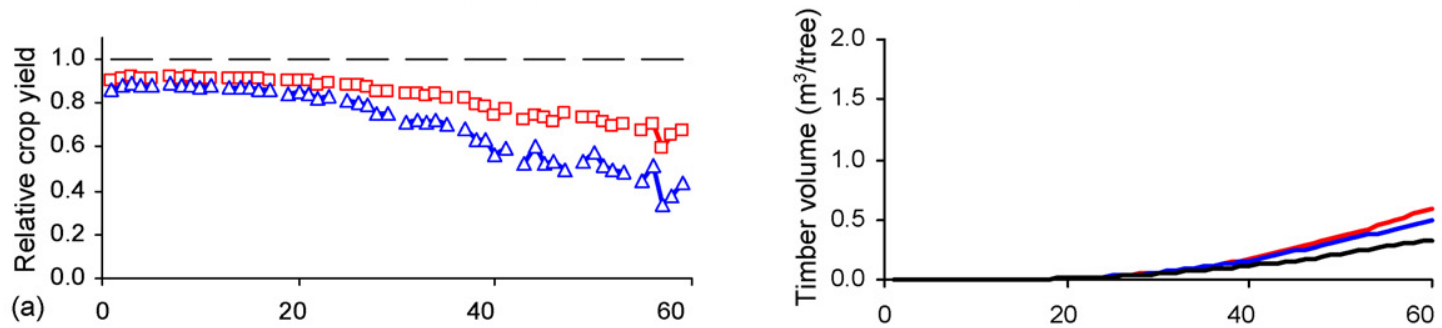

Land unit 1, Champdeniers, France (wild cherry; wheat/wheat/s/wheat/oilseed/sunflower)
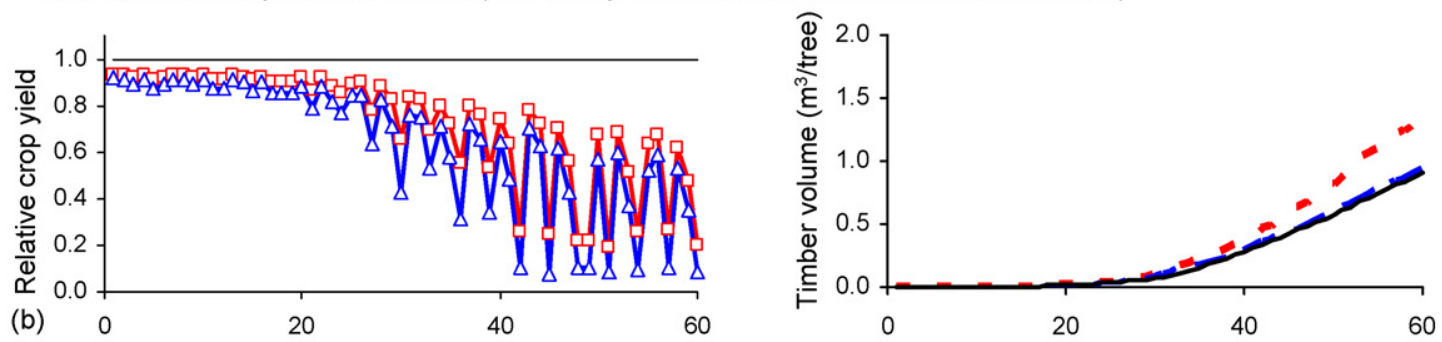

Land unit 2, Champdeniers, France (walnut; wheat/wheat/s/wheat/oilseed/sunflower)
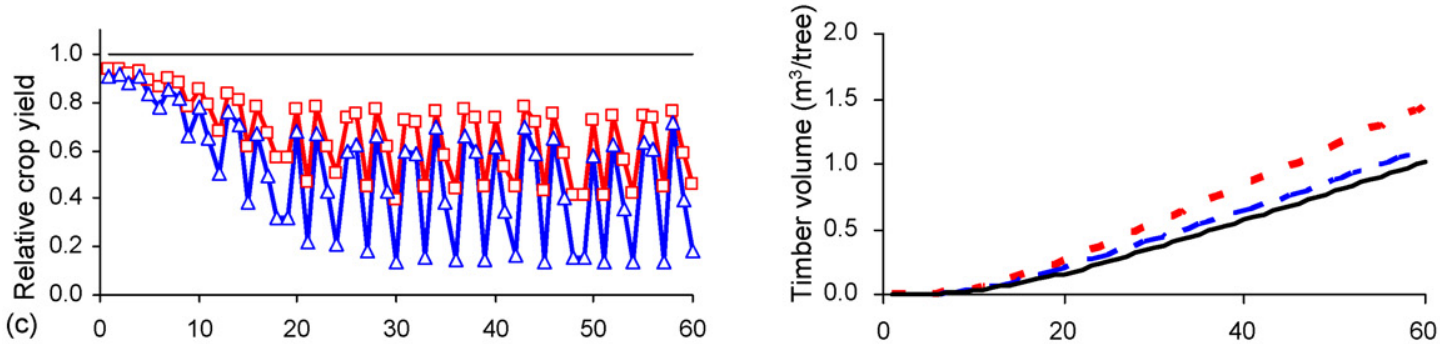

Land unit 1, Sherpenzeel, the Netherlands (poplar; forage maize)
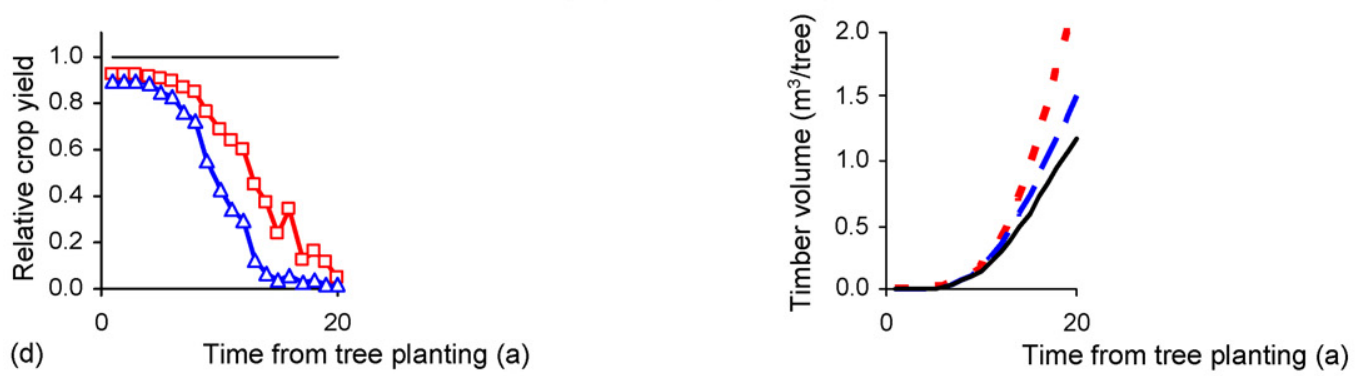

$\longrightarrow$ Arable $\longrightarrow$ - 50 trees/ha $\longrightarrow-113$ trees/ha

- -50 trees/ha - - 113 trees/ha $\longrightarrow$ Forestry

Fig. 1 - Prediction of relative crop yields and timber volumes over time for (a) oak, (b) wild cherry, (c) walnut, and (d) poplar silvoarable systems (50 and 113 trees $\mathrm{ha}^{-1}$ ) on four different land units. 


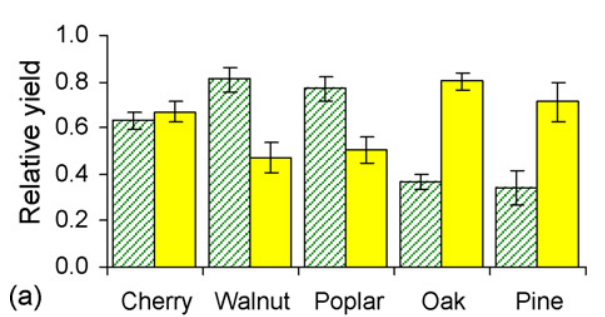

$\square$ Relative tree yield

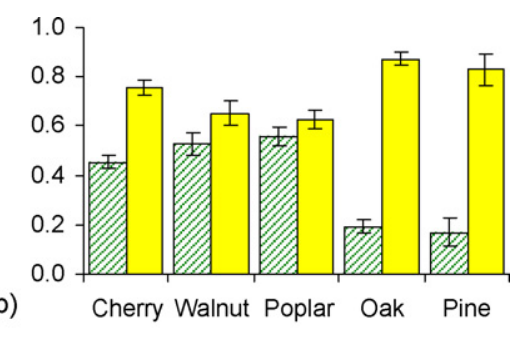

Relative crop yield

Fig. 2 - Predicted tree and crop yields (over a tree rotation) in cherry, walnut, poplar, oak, and pine silvoarable systems at (a) 113 trees ha ${ }^{-1}$ and (b) 50 trees ha ${ }^{-1}$, relative to monoculture yields (error bars show confidence intervals for mean values).

forestry systems, the timber volume per tree ranged from $0.23 \mathrm{~m}^{3}$ for holm oak after 60 years, to $1.59 \mathrm{~m}^{3}$ for poplar after 20 years. Standard deviations showed that absolute yield variation was relatively high for wild cherry in France and poplar in The Netherlands; coefficients of variation showed that relative yield variation was relatively high for oak in Spain, wild cherry in France, and poplar in The Netherlands.

For each crop, except wheat in Spain, there was a significant positive correlation between predicted annual crop yields and soil depth (Table 4). Predicted timber yields were also positively correlated with soil depth for cherry, poplar, and oak (Table 4). However, this correlation was only significant $(P=0.05)$ in the case of wild cherry.

\subsection{Yields in silvoarable systems}

The biophysical outputs from Yield-SAFE for the silvoarable systems (50 and 113 trees ha $^{-1}$ ) showed a general decline in crop yields as the trees became larger and competed more effectively for light and water (Fig. 1). Oak (Fig. 1a) and stone pine (which showed similar growth over time to oak and is therefore not shown) grew slowly throughout the whole rotation. Hence, relatively high crop yields were sustained for most of the tree rotation. The initial rate of timber formation by wild cherry (Fig. 1b) was slow compared with walnut (Fig. 1c) and poplar (Fig. 1d), and crop yield reduction in the walnut and poplar systems was predicted to occur earlier than in the wild cherry systems. As expected, crop yields and tree growth (on a per tree basis) were greater in 50 tree ha $^{-1}$ systems than in 113 tree ha ${ }^{-1}$ systems (Fig. 1).
Over the whole length of the tree rotation, crop yields relative to those in arable systems were greatest in the 50 tree ha $^{-1}$ systems and timber yields relative to those in forestry systems were greatest in the 113 tree ha $^{-1}$ systems (Fig. 2). During a full tree rotation, in both France and Spain, the relative yield obtained for autumn-planted wheat tended to be greater than that for spring-planted sunflower (Fig. 3a and b). Similarly, under poplar in The Netherlands (Fig. 3c), the relative yield obtained for wheat (autumn-planted) was greater than that for forage maize (spring-planted). Relative timber production also varied between species. At 113 trees ha $^{-1}$ relative timber production was higher for walnut, wild cherry, and poplar (63-81\%) then for oak and stone pine (34-37\%) (Fig. 2a); a similar pattern between the species was evident at 50 trees per $\mathrm{ha}^{-1}$, but the relative yields (45-56\% and $17-19 \%$, respectively) were lower (Fig. 2b).

\subsection{Land equivalent ratios}

With a few exceptions, and including thinnings for timber and a full rotation for crop yields, the predicted land equivalent ratios of the silvoarable systems (Eq. (1)) at both 113 and 50 trees ha ${ }^{-1}$ were between 1 and 1.4. Hence, the Yield-SAFE model predicted that, under typical management, integrating crops and trees on the same area of land was more productive than growing them separately. The relationship between relative tree and crop yields suggested that the land equivalent ratio would form a convex arc, with maximum values obtained when the trees and crops had similar relative yields, and minimum values where either the tree or crop compo-
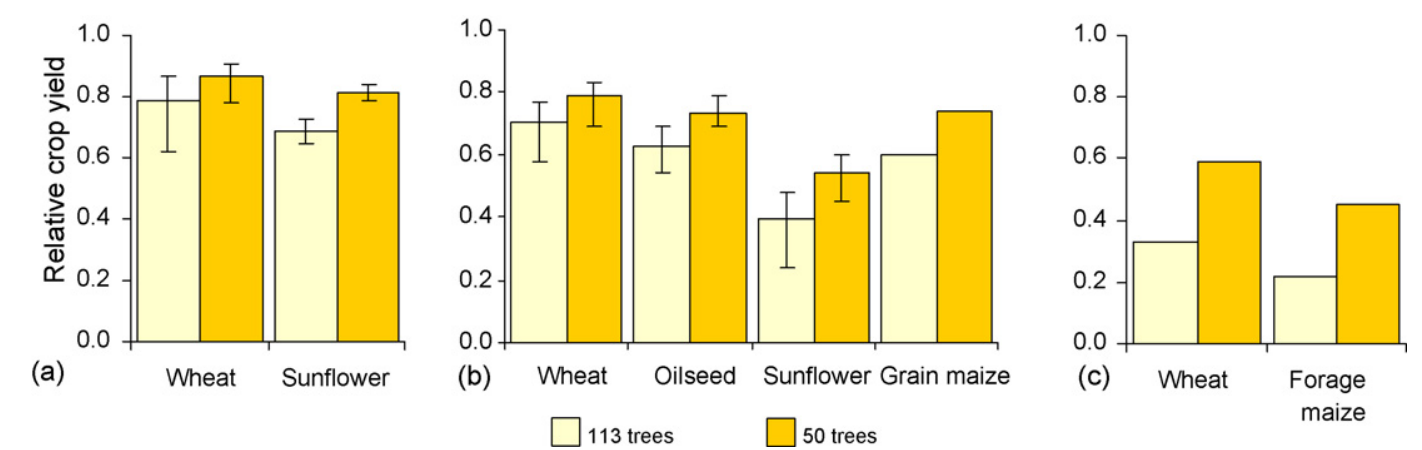

Fig. 3 - Predicted crop yields (over a tree rotation) in silvoarable systems of 113 and 50 trees ha ${ }^{-1}$ in (a) Spain and (b) France under all tree species, and (c) The Netherlands under poplar, relative to monoculture yields (error bars show the maximum and minimum values in each group). 
nent was dominant (Fig. $4 \mathrm{a}$ and b). At each landscape test site, the land equivalent ratio at 113 trees ha ${ }^{-1}$ (Fig. 4a) was greater than that at 50 trees ha $^{-1}$ (Fig. 4b). At both tree densities, the highest land equivalent ratios were associated with poplar, walnut and cherry systems in France (Fig. 4); the lowest land equivalent ratios were associated with oak and pine in Spain.

\subsection{Definition of revenue, costs, and grants}

The revenue and costs associated with the tree and crop systems are fully described by Graves (2005). However, for clarity some key values are described here.

\subsubsection{Arable and silvoarable crop component finance}

The values for arable crops ranged from $85 € \mathrm{t}^{-1}$ for grain maize to $280 € \mathrm{t}^{-1}$ for sunflower; the values for wheat grain ranged from 102 to $142 € \mathrm{t}^{-1}$. The variable costs tended to be lowest in Spain, at between 45 and $189 € \mathrm{ha}^{-1}$, and highest in The Netherlands, at between 457 and $479 €$ ha $^{-1}$. The assignable fixed costs, such as machinery and labour costs, followed a similar pattern, tending to be lowest in Spain and highest in The Netherlands.

\subsubsection{Forestry and silvoarable tree component finance}

In Spain, the values recorded for oak $\left(17 € \mathrm{~m}^{-3}\right)$ and pine $\left(8-19 € \mathrm{~m}^{-3}\right)$ were relatively low. By contrast, in France, the values recorded for walnut $\left(40-1300 € \mathrm{~m}^{-3}\right)$, wild cherry
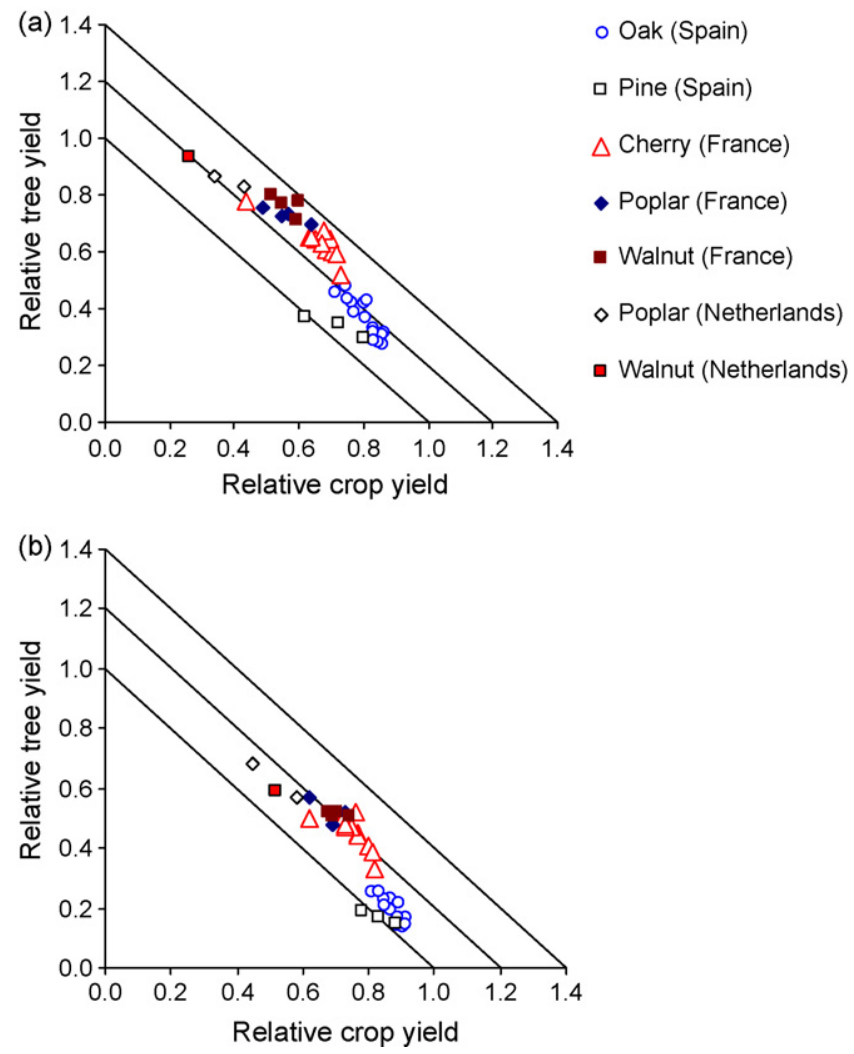

Fig. 4 - Relationship between relative crop yield and relative tree yield for the walnut and poplar (France and The Netherlands), cherry (France), and oak and pine silvoarable systems (Spain) at (a) 113 trees ha-1 and (b) 50 trees ha $^{-1}$.
(10-380€ $\left.\mathrm{m}^{-3}\right)$, and poplar $\left(7-55 € \mathrm{~m}^{-3}\right)$ were relatively high. In The Netherlands, the value recorded for walnut $\left(18-41 € \mathrm{~m}^{-3}\right)$ was much lower than in France, but the value of poplar $\left(19-97 € \mathrm{~m}^{-3}\right)$ was slightly higher.

The establishment costs of forestry systems were greatest in The Netherlands ( $3420 € \mathrm{ha}^{-1}$ for walnut; $1940 € \mathrm{ha}^{-1}$ for poplar) and lowest in Spain $\left(770 € \mathrm{ha}^{-1}\right)$ for oak systems at 400 trees ha ${ }^{-1}$. The establishment costs for forestry systems of cherry $\left(1510 € \mathrm{ha}^{-1}\right)$, walnut $\left(1633 € \mathrm{ha}^{-1}\right)$, and poplar $\left(1260 € \mathrm{ha}^{-1}\right)$ in France and high-density oak (1470€ ha-1) and pine $\left(1786 € \mathrm{ha}^{-1}\right)$ in Spain were intermediate. The establishment cost of the tree component in the 113 tree ha ${ }^{-1}$ silvoarable systems ranged from $1200 € \mathrm{ha}^{-1}$ for walnut in The Netherlands, to $233 € \mathrm{ha}^{-1}$ for oak in Spain. Management costs after establishment were highest for the systems in France and The Netherlands, where control of undergrowth and pruning involved substantial costs. In addition, in The Netherlands, an annual opportunity cost of $408 €$ ha $^{-1}$ was assumed for arable land converted to forest, because of the problem of finding land for slurry application; this cost was applied on a pro-rata basis to the tree-rows in the silvoarable system.

\subsubsection{Grant regimes}

Under the pre-2005 grant regime, the cash value (discount rate $=0 \%$ ) of forestry payments was greatest in The Netherlands and lowest in France (Table 5). The arable area payments were marginally greater in The Netherlands than in France, but both were much greater than those for the chosen systems in Spain.

In Spain, support for silvoarable agroforestry was lower than for forestry and the arable systems, because of ineligibility for tree grants and reduction of the crop payments according to a canopy-area based calculation. In France, in Poitou Charentes and Centre (Champdeniers, Fussy, Sancerre, and Chateauroux), arable payments were at least five times the value of forestry payments; the value of silvoarable payments was marginally less than that for arable systems. In Champlitte, Dampierre, and Vitrey in Franche Comté, there were no forestry payments. Support for walnut and poplar forestry in The Netherlands was identical, because both were assumed to be temporary, production-based systems. Since arable payments were dependent on the length of the tree rotation, they were greater for walnut (Bentelo) than for poplar (Balkbrug and Scherpenzeel). In each case, the support for silvoarable systems was less than for forestry and arable systems, as no payments were received for the tree component.

In the post-2005 grant regime, existing levels of payments for forestry applied where they were in accordance with the rural development strategy of the European Union (European Commission, 2004). There was therefore no change in France. However, in Spain and The Netherlands, planting payments were changed to $50 \%$ of tree costs in the first 4 years and the compensation payments and maintenance grants were reduced to $500 € \mathrm{ha}^{-1} \mathrm{a}^{-1}$ with a maximum duration of 10 years, unless they were already below these levels. In general, arable and especially silvoarable payments were predicted to increase in Spain. The predicted value of the new single farm payment at Alcala, Paramo, and Campo was greater than pre- 
Table 5 - The predicted value of government support $\left(€ \mathrm{ha}^{-1}\right)$, over a full tree-rotation (60 years for oak, pine walnut and cherry; 20 years for poplar), for forestry, arable and silvoarable systems in the pre-2005 grant regime, and the predicted change in that support in a post-2005 grant regime (scenario 1 and scenario 2)

Country, tree species and land unit
Pre-2005 government support

$\overline{\text { Rotation Forestry Arable Silvoarable }}$

(a)
Predicted net change in support with the post-2005 grant regime

\begin{tabular}{|c|c|c|c|c|c|c|c|c|c|}
\hline \multicolumn{10}{|l|}{ Spain } \\
\hline \multirow[t]{16}{*}{ Oak } & Alcala 1 & 60 & 6,860 & 5,170 & 2,010 & -2940 & 8,030 & 10,010 & 11,410 \\
\hline & Alcala 2 & 60 & 6,860 & 5,170 & 2,690 & -2940 & 8,030 & 9,320 & 10,730 \\
\hline & Torrijos 1 & 60 & 9,380 & 3,870 & 1,410 & -4190 & 210 & 820 & 1,260 \\
\hline & Torrijos 2 & 60 & 9,380 & 5,170 & 1,920 & -4180 & 270 & 1,790 & 2,380 \\
\hline & Ocaña 1 & 60 & 9,380 & 5,170 & 1,770 & -4190 & 350 & 2,120 & 2,860 \\
\hline & Almonacid 1 & 60 & 9,380 & 3,870 & 1,380 & -4190 & 600 & 2,010 & 2,710 \\
\hline & Almonacid 2 & 60 & 9,370 & 8,770 & 4,080 & -4180 & $-1,030$ & 2,980 & 3,890 \\
\hline & Cardenosa 1 & 60 & 8,860 & 5,810 & 2,900 & -3380 & $-5,90$ & 1,850 & 2,540 \\
\hline & Cardenosa 2 & 60 & 8,860 & 5,810 & 2,670 & -3390 & -590 & 2,080 & 2,770 \\
\hline & Fontiveros 1 & 60 & 8,850 & 6,200 & 2,940 & -3380 & 950 & 3,570 & 4,430 \\
\hline & Olmedo 2 & 60 & 8,860 & 5,160 & 2,260 & -3390 & 600 & 2,990 & 3,720 \\
\hline & Olmedo 3 & 60 & 8,860 & 6,100 & 2,520 & -3380 & -340 & 2,720 & 3,460 \\
\hline & Campo 2 & 60 & 8,860 & 6,460 & 2,610 & -3380 & 1,990 & 4,160 & 6,060 \\
\hline & Paramo 1 & 60 & 8,860 & 6,760 & 3,080 & -3390 & 2,500 & 5,350 & 6,400 \\
\hline & Paramo 2 & 60 & 8,860 & 6,760 & 3,080 & -3390 & 2,500 & 5,350 & 6,400 \\
\hline & Paramo 3 & 60 & 8,860 & 6,760 & 3,060 & -3390 & 2,500 & 5,370 & 6,420 \\
\hline \multirow[t]{3}{*}{ Pine } & Fontiveros 2 & 60 & 8,000 & 6,200 & 2,060 & -2960 & 950 & 4,450 & 5,340 \\
\hline & Olmedo 1 & 60 & 8,010 & 6,100 & 1,780 & -2970 & -340 & 3,470 & 4,220 \\
\hline & Campo 1 & 60 & 8,010 & 5,810 & 1,050 & -2970 & 1,790 & 2,640 & 4,260 \\
\hline \multicolumn{10}{|l|}{ France } \\
\hline \multirow[t]{12}{*}{ Cherry } & Champdeniers 1 & 60 & 4,440 & 21,180 & 16,130 & 0 & 0 & -390 & 1,560 \\
\hline & Fussy 3 & 60 & 3,840 & 21,090 & 19,590 & 0 & -30 & -430 & 1,870 \\
\hline & Sancerre 3 & 60 & 3,840 & 20,860 & 19,380 & 0 & -70 & -460 & 1,800 \\
\hline & Fussy 1 & 60 & 3,840 & 21,090 & 19,590 & 0 & -30 & -420 & 1,870 \\
\hline & Chateauroux 2 & 60 & 3,840 & 21,000 & 19,510 & 0 & -50 & -440 & 1,840 \\
\hline & Chateauroux 4 & 60 & 3,840 & 21,000 & 19,510 & 0 & -50 & -440 & 1,840 \\
\hline & Sancerre 4 & 60 & 3,850 & 20,940 & 19,450 & 0 & -150 & -530 & 1,740 \\
\hline & Sancerre 1 & 60 & 3,840 & 20,860 & 19,380 & 0 & -70 & -460 & 1,810 \\
\hline & Champlitte 1 & 60 & 0 & 20,080 & 11,880 & 0 & -100 & -60 & 2,170 \\
\hline & Dampierre 1 & 60 & 0 & 21,040 & 15,320 & 0 & $-1,300$ & $-1,550$ & 870 \\
\hline & Vitrey 1 & 60 & 0 & 19,840 & 14,450 & 0 & -60 & -50 & 2,760 \\
\hline & Dampierre 2 & 60 & 0 & 20,940 & 12,700 & 0 & $-1,200$ & -730 & 860 \\
\hline \multirow[t]{4}{*}{ Walnut } & Champdeniers 2 & 60 & 4,270 & 21,180 & 16,440 & 0 & 0 & -700 & 1,570 \\
\hline & Chateauroux 3 & 60 & 3,670 & 20,800 & 19,630 & 0 & 150 & -570 & 2,030 \\
\hline & Chateauroux 1 & 60 & 3,680 & 21,000 & 19,820 & 0 & -50 & -750 & 1,840 \\
\hline & Champlitte 2 & 60 & 0 & 19,880 & 3,920 & 0 & 100 & 20 & 3,450 \\
\hline \multirow[t]{4}{*}{ Poplar } & Sancerre 2 & 20 & 2,720 & 6,940 & 6,850 & 0 & -10 & -540 & 610 \\
\hline & Fussy 2 & 20 & 2,720 & 6,960 & 6,870 & 0 & 60 & -480 & 680 \\
\hline & Dampierre 3 & 20 & 0 & 7,080 & 3,870 & 0 & -500 & -280 & 610 \\
\hline & Vitrey 2 & 20 & 0 & 6,600 & 3,610 & 0 & -10 & -10 & 880 \\
\hline \multicolumn{10}{|c|}{ The Netherlands } \\
\hline Walnut & Bentelo & 60 & 11,810 & 23,000 & 5,230 & -1980 & -1820 & -410 & 2,810 \\
\hline \multirow[t]{2}{*}{ Poplar } & Balkbrug & 20 & 11,810 & 8,000 & 3,640 & -3310 & 0 & 0 & 1,030 \\
\hline & Sherpenzeel & 20 & 11,810 & 8,000 & 4,370 & -3640 & 0 & 0 & 1,100 \\
\hline
\end{tabular}

2005 area payments, as the generous support for non-arable activities on the farms typical of these areas, was assumed to be re-allocated on an area basis. In France, there were only marginal changes for arable systems, due to modulation under the single farm payment. For silvoarable systems, scenario 1 was generally similar to the pre-2005 regime but marginal benefits were evident under scenario 2.

\subsection{Plot-scale economic results}

\subsubsection{Profitability with no grants}

The equivalent annual values of the forestry systems with oak and stone pine in Spain, poplar and walnut in The Netherlands, and cherry in France were negative (Table 6). Only walnut and poplar in France was profitable. The equiv- 
Table 6 - Equivalent annual value $\left(€ \mathrm{ha}^{-1} \mathrm{a}^{-1}\right)$ (discount rate of $4 \%$ ) of the arable, forestry, and silvoarable (113 trees ha ${ }^{-1}$ system in Spain, France and The Netherlands, (a) without grants, (b) under the pre-2005 grant regime, and (c) the post-2005 grant regime (scenario 1 and 2)

\begin{tabular}{|c|c|c|c|c|c|c|c|c|c|c|c|}
\hline \multirow{2}{*}{\multicolumn{2}{|c|}{$\begin{array}{l}\text { Country, tree species } \\
\text { and land unit }\end{array}$}} & \multicolumn{3}{|c|}{ (a) No grants } & \multicolumn{3}{|c|}{ (b) Pre-2005 } & \multicolumn{4}{|c|}{ (c) Post-2005 } \\
\hline & & Forestry & Crop & Silvoarable & Forestry & Crop & Silvoarable & Forestry & Crop & $\begin{array}{l}\text { Silvoarable } \\
\text { scenario } 1\end{array}$ & $\begin{array}{l}\text { Silvoarable } \\
\text { scenario } 2\end{array}$ \\
\hline \multicolumn{12}{|l|}{ Spain } \\
\hline \multirow[t]{16}{*}{ Oak } & Alcala 1 & -57 & 99 & 67 & 184 & 191 & 125 & 97 & 333 & 279 & 310 \\
\hline & Alcala 2 & -50 & 47 & 30 & 190 & 139 & 97 & 103 & 281 & 242 & 272 \\
\hline & Torrijos 1 & -36 & -13 & -5 & 290 & 56 & 23 & 166 & 59 & 36 & 51 \\
\hline & Torrijos 2 & -37 & -39 & -9 & 289 & 53 & 11 & 166 & 57 & 35 & 52 \\
\hline & Ocaña 1 & -37 & -32 & -11 & 289 & 59 & 29 & 166 & 66 & 42 & 50 \\
\hline & Almonacid 1 & -40 & -20 & -13 & 286 & 48 & -56 & 163 & 59 & 36 & 52 \\
\hline & Almonacid 2 & -46 & 18 & 0 & 280 & 172 & 108 & 157 & 154 & 124 & 145 \\
\hline & Cardenosa 1 & -59 & 113 & 98 & 245 & 215 & 172 & 156 & 205 & 182 & 200 \\
\hline & Cardenosa 2 & -55 & 115 & 98 & 248 & 218 & 169 & 160 & 207 & 181 & 199 \\
\hline & Fontiveros 1 & -56 & 100 & 72 & 248 & 210 & 162 & 159 & 226 & 200 & 221 \\
\hline & Olmedo 2 & -54 & 58 & 38 & 250 & 149 & 105 & 161 & 160 & 136 & 154 \\
\hline & Olmedo 3 & -55 & 8 & -9 & 248 & 115 & 62 & 160 & 109 & 85 & 103 \\
\hline & Campo 2 & -57 & -54 & -25 & 247 & 61 & 8 & 158 & 96 & 61 & 84 \\
\hline & Paramo 1 & -51 & 196 & 176 & 253 & 315 & 258 & 164 & 360 & 325 & 349 \\
\hline & Paramo 2 & -51 & 196 & 176 & 253 & 315 & 258 & 164 & 360 & 325 & 349 \\
\hline & Paramo 3 & -50 & 195 & 175 & 253 & 314 & 257 & 165 & 359 & 324 & 348 \\
\hline \multirow[t]{3}{*}{ Pine } & Fontiveros 2 & -80 & 100 & 57 & 190 & 210 & 129 & 118 & 227 & 181 & 203 \\
\hline & Olmedo 1 & -80 & 7 & -15 & 190 & 115 & 34 & 118 & 109 & 71 & 90 \\
\hline & Campo 1 & -80 & -73 & -34 & 190 & 30 & -9 & 118 & 61 & 13 & 34 \\
\hline \multicolumn{12}{|l|}{ France } \\
\hline \multirow[t]{12}{*}{ Cherry } & Champdeniers 1 & -111 & 14 & 68 & 63 & 380 & 353 & 63 & 381 & 336 & 384 \\
\hline & Chateauroux 2 & -152 & 35 & 40 & 0 & 398 & 353 & 0 & 398 & 335 & 385 \\
\hline & Chateauroux 4 & -153 & 31 & 37 & -2 & 395 & 349 & -2 & 394 & 332 & 382 \\
\hline & Fussy 1 & -166 & 114 & 79 & -14 & 479 & 399 & -14 & 479 & 381 & 431 \\
\hline & Fussy 3 & -90 & 317 & 277 & 62 & 682 & 607 & 62 & 682 & 589 & 639 \\
\hline & Sancerre 1 & -155 & 18 & 15 & -3 & 380 & 327 & -3 & 379 & 309 & 359 \\
\hline & Sancerre 3 & -59 & 249 & 262 & 92 & 610 & 580 & 92 & 609 & 561 & 611 \\
\hline & Sancerre 4 & -146 & 24 & 31 & 6 & 387 & 341 & 6 & 384 & 321 & 371 \\
\hline & Champlitte 1 & -73 & 127 & 187 & -73 & 474 & 435 & -73 & 473 & 434 & 478 \\
\hline & Dampierre 1 & -79 & 48 & 120 & -79 & 412 & 408 & -79 & 390 & 390 & 435 \\
\hline & Dampierre 2 & -144 & -207 & -37 & -144 & 156 & 131 & -144 & 135 & 115 & 159 \\
\hline & Vitrey 1 & -108 & -61 & 16 & -108 & 283 & 256 & -108 & 282 & 256 & 301 \\
\hline \multirow[t]{4}{*}{ Walnut } & Champdeniers 2 & 227 & 91 & 296 & 394 & 458 & 535 & 394 & 459 & 504 & 566 \\
\hline & Chateauroux 1 & 182 & 154 & 287 & 327 & 517 & 578 & 327 & 517 & 547 & 610 \\
\hline & Chateauroux 3 & 231 & 269 & 354 & 376 & 629 & 691 & 376 & 632 & 662 & 726 \\
\hline & Champlitte 2 & 224 & -166 & 227 & 224 & 178 & 296 & 224 & 180 & 297 & 342 \\
\hline \multirow[t]{4}{*}{ Poplar } & Fussy 2 & 232 & 219 & 318 & 417 & 581 & 634 & 417 & 584 & 598 & 670 \\
\hline & Sancerre 2 & 414 & 271 & 508 & 599 & 632 & 803 & 599 & 631 & 764 & 835 \\
\hline & Dampierre 3 & 309 & -132 & 270 & 309 & 236 & 401 & 309 & 210 & 385 & 445 \\
\hline & Vitrey 2 & 262 & -128 & 250 & 262 & 215 & 358 & 262 & 215 & 357 & 417 \\
\hline \multicolumn{12}{|c|}{ The Netherlands } \\
\hline Walnut & Bentelo 1 & -1063 & 248 & -161 & -659 & 646 & -16 & -669 & 615 & -30 & 36 \\
\hline \multirow[t]{2}{*}{ Poplar } & Balkbrugg 1 & -521 & 187 & 216 & 151 & 603 & 356 & 35 & 603 & 356 & 426 \\
\hline & Scherpenzeel 1 & -756 & 131 & 140 & -84 & 547 & 310 & -221 & 547 & 310 & 384 \\
\hline
\end{tabular}

alent annual values of the arable system were positive at Alcala, Cardenosa, Fontiveros, Olmedo, and Paramo in Spain, at Champdeniers, Chateauroux, Fussy, and Sancerre in France, and at all sites in The Netherlands. By contrast the returns from arable systems were negative in Torrijos, Ocaña, and Campo and at most sites in Franche Comté (i.e. at Dampierre and Vitrey) (Table 6). The equivalent annual value of the silvoarable systems in Spain were marginally below those for the arable system. By contrast, in France, values for the silvoarable systems with walnut, with poplar in Centre, and with wild cherry in Poitou Charentes and Franche Comté were higher than those for both arable cropping and forestry. In The Netherlands, the values for the silvoarable system with poplar were marginally greater than the arable system, but the value for the silvoarable system with walnut was negative (Table 6). 


\subsubsection{Pre-2005 grant regime}

In the pre-2005 grant regime (Table 6), the equivalent annual values of forestry systems in Spain were generally higher than those of arable systems, except where crop yields were high. The equivalent annual values of silvoarable systems were generally lower than for forestry and arable systems. In France, the equivalent annual values of arable systems were generally greater than those for wild cherry silvoarable systems, which were much greater than those for wild cherry forestry. The predicted equivalent annual values of the poplar and walnut silvoarable systems were higher than those for both forestry and arable systems. In The Netherlands, the equivalent annual values of arable systems were greatest, followed by those for silvoarable and then forestry systems.

\subsubsection{Post-2005 grant regime}

In the post-2005 grant regime (Table 6), the equivalent annual values for forestry in Spain declined in comparison with those for forestry in the pre-2005 grant regime, but increased for arable and silvoarable systems despite modulation. In France, the equivalent annual values were broadly similar to those under the pre-2005 regime, although for silvoarable systems, scenario 1 resulted in marginal reductions, while scenario 2 resulted in marginal increases in equivalent annual values. In The Netherlands, a substantial decrease in the equivalent annual values of forestry was predicted, but the change in the equivalent annual values of arable systems was marginal. For silvoarable systems, little change was predicted for scenario 1 , but a small and consistent increase was predicted for scenario 2 .

\subsection{Farm-scale analysis}

In Spain, under the pre-2005 grant regime, there were no cases where establishing a silvoarable system increased farm profitability relative to the status quo (Fig. 5). By contrast, under the pre-2005 grant regime, forestry was attractive in about $80 \%$ of cases. The post- 2005 regime was predicted to reduce the relative profitability of forestry, but forestry still remained financially attractive on about $50 \%$ of the selected farms. In France, under the pre-2005 grant regime, silvoarable systems

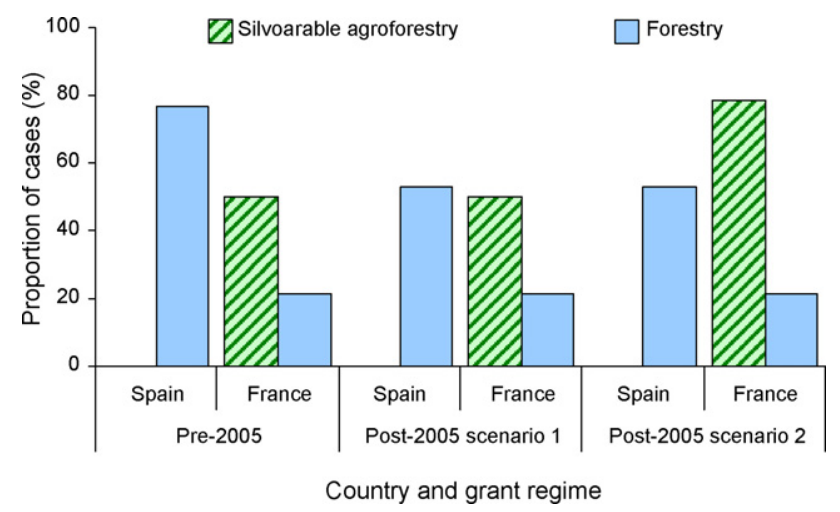

Fig. 5 - Proportion of cases where the net present value of hypothetical arable farms was improved by introducing silvoarable systems (113 trees ha $\left.{ }^{-1}\right)$ and forestry systems (Spain: $n=17$ and France: $n=14$ ).

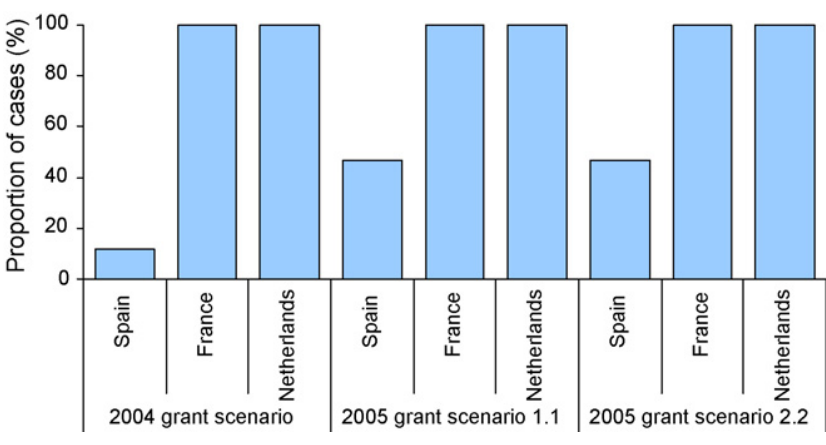

Fig. 6 - Proportion of cases in which the net present value of hypothetical farms was improved more by silvoarable systems (113 trees $\mathrm{ha}^{-1}$ ) than by forestry systems (Spain: $n=17$; France: $n=14$; The Netherlands: $n=3$ ).

were predicted to increase farm profitability in approximately $50 \%$ of cases. This frequency remained similar under scenario 1 of the post-2005 grant regime, and increased to $80 \%$ under scenario 2 . The proportion of farms where forestry was attractive $(20 \%)$ was less than for silvoarable systems and was the same for both the pre- and post-2005 grant regimes. In The Netherlands (not shown), the introduction of forestry and silvoarable systems always reduced farm profitability under both pre- and post-2005 grant regimes.

In Spain, the use of silvoarable systems was preferable to forestry in $12 \%$ of cases under the pre-2005 grant regime and $50 \%$ of cases in scenarios 1 and 2 of the post-2005 grant regime (Fig. 6). In France and The Netherlands, farm profitability was always increased with the use of silvoarable rather than forestry systems.

\section{Discussion}

A process for modelling tree and crop yields, and the plot- and farm-scale economics of arable, forestry, and silvoarable systems in three European countries was developed and has been described. This process provided a systematic method for determining the effects of tree spacing, tree and crop species, and grant regime on the profitability of silvoarable systems relative to arable and forestry systems.

\subsection{Biophysical modelling of yields}

In Spain, the relative yields of autumn-planted crops, such as wheat, tended to be greater than those for spring-planted crops, such as sunflower (Fig. 3a). As oak and stone pine are evergreen trees and competition for light was similar for both spring- and autumn-planted crops, this may have been due to greater competition for water experienced by the spring-planted crop. In France, the difference in the relative yield of the autumn- (i.e. wheat and oilseed) and springplanted (sunflower and grain maize) crops was larger than in Spain (Fig. 3b). This was probably due to reduced competition for light, because the tree species planted in France were deciduous, and hence, had no leaves for a large proportion of the growing period of the autumn-planted crops. In The Netherlands (Fig. 3c), the differences between relative 
yields of autumn-planted wheat and spring-planted forage maize under poplar followed the same pattern. Similar benefits from using autumn- rather than spring-planted crops were observed by Burgess et al. (2004a,b) with poplar in the UK. Relative timber yields varied according to density and species (Fig. 2). Timber production on a per tree basis was greater at 50 than at 113 trees ha ${ }^{-1}$ as per tree resource use was greater at lower densities. However, per area timber production was greatest for 113 trees ha ${ }^{-1}$ and for wild cherry, walnut, and poplar, suggesting that higher tree densities and faster-growing species had allowed the tree component to capture a greater share of the available resources.

Although Yield-SAFE predicted lower timber yields and crop yields per hectare for silvoarable systems compared to the arable and forestry systems, respectively (Fig. 2), the total productivity of silvoarable systems, determined with land equivalent ratios, was predicted to be between 100 and $140 \%$ of that for the monoculture systems (Fig. 4). The highest ratios were obtained by integrating deciduous trees and autumnplanted crops, which were complementary in terms of light use, suggesting that silvoarable systems would be most advantageous over arable and forestry monocropping, where such species can be combined. High land equivalent ratios were also associated with the higher tree stand densities of 113 rather than of 50 trees ha ${ }^{-1}$, suggesting that at 50 trees ha ${ }^{-1}$ silvoarable systems were sub-optimal in terms of light and water use, and that the higher tree stand density would be preferable for increased productivity. Finally, high land equivalent ratios at both tree densities were associated with faster growing trees like poplar, walnut, and wild cherry in France whilst in Spain, oak and pine systems at both densities were associated with much lower land equivalent ratios (Fig. 4). The reasons for this are not clear. It may be that oak and pine growth was so slow that neither species was able to make use of available resources at the densities used in the silvoarable systems; alternatively, it is possible that crops competed more strongly for water than other trees of the same species. In either case, production benefits from oak and pine-based silvoarable systems in Spain appear to be limited unless the tree density can be increased without detriment to the relative yield of either component.

\subsection{Grant regimes}

In the pre-2005 grant regime, support for silvoarable systems was frequently less than that for arable and forestry systems. In arable systems, crop payments in Spain $\left(129-176 € \mathrm{ha}^{-1}\right)$ and in France and The Netherlands $\left(324-400 € \mathrm{ha}^{-1}\right)$ were assumed for every year of cropping. In forestry systems, generous schemes could make forestry payments greater then silvoarable payments. Thus, in Spain, planting grants of $849-1593 € \mathrm{ha}^{-1}$, compensation payments of $225-325 € \mathrm{ha}^{-1} \mathrm{a}^{-1}$ for 20 years, and maintenance payments of $180-288 € \mathrm{ha}^{-1} \mathrm{a}^{-1}$ for 5 years, could be obtained. In The Netherlands, planting grants of $95 \%$ of costs up to a maximum of $1500 € \mathrm{ha}^{-1}$, compensation payments of $100 € \mathrm{ha}^{-1} \mathrm{a}^{-1}$ for 5 years, and maintenance payments of $545 € \mathrm{ha}^{-1} \mathrm{a}^{-1}$ for 18 years, were available. However, guidelines developed for payments on silvoarable systems resulted in disadvantages. These included termination of crop payments if cropping stopped before the tree rotation finished and reduction of crop payments by the uncropped proportion of the system in France and The Netherlands, and by twice the proportion of the tree canopy in the system in Spain. Payments on the tree component did not compensate for these losses. In the Poitou Charentes and Centre regions of France, planting grants covered $50 \%$ of tree costs in the first 4 years of the tree rotation, but in Spain, The Netherlands and the Franche Comte region in France, the tree component received no payments at all.

Under the post-2005 grant regime, the per hectare value of the single farm payments in Spain $\left(68-220 € \mathrm{ha}^{-1} \mathrm{a}^{-1}\right)$ were higher than crop payments under the pre-2005 grant regime, because payments for other farm activities were included in the calculation. In France and The Netherlands, the per hectare value of the single farm payments $\left(329-400 € \mathrm{ha}^{-1} \mathrm{a}^{-1}\right.$ ) declined marginally because of modulation. Forestry payments in Spain and The Netherlands also declined, mostly because the duration of compensation payments was reduced from 20 and 18 years to 10 years, respectively. In France, little change was evident for forestry. However, support for silvoarable systems generally improved relative to arable and forestry systems. For example, silvoarable payments for both scenarios 1 and 2 in Spain, were greatly improved in absolute terms and relative to payments for arable and forestry systems. In France and The Netherlands, the difference was less striking, although in The Netherlands, the value of silvoarable payments improved substantially relative to forestry payments. Under scenario 2 , where a planting grant was added to the full single farm payment, absolute payments on silvoarable systems could marginally exceed payments for arable systems (providing cropping did not stop before the tree rotation ended). In these circumstances, farmers might be encouraged to retain existing trees already on arable land, since they are no longer the direct cause of lost payments. However, the planting grants calculated for Spain $\left(214-370 € \mathrm{ha}^{-1}\right)$, France (393-793€ ha-1), and The Netherlands $\left(670-1133 € \mathrm{ha}^{-1}\right.$ ) are small in proportion to the total grant payable for maintaining the land in arable production and, on their own, are unlikely to encourage widespread adoption of silvoarable systems.

\subsection{Plot-scale economics}

Without grants, silvoarable systems were frequently the most profitable system at the landscape test sites (Table 6). In Spain, oak and stone pine silvoarable systems were the most profitable system in 6 of 19 land units. In France, walnut silvoarable systems were the most profitable system in four out of four land units, poplar silvoarable systems the most profitable system in 2 out of 4 land units, and wild cherry silvoarable systems the most profitable system in 9 out of 12 land units. In The Netherlands, poplar silvoarable systems were the most profitable system in 2 out of 2 land units.

However, the pre-2005 grant regime altered the profitability of silvoarable systems, relative to arable and forestry systems (Table 6). This was especially the case in Spain, where silvoarable systems became the least profitable system on all 19 land units. In France, walnut silvoarable systems remained the most profitable system on each of the four land units and poplar silvoarable profitability increased relative to forestry to also become the most profitable system on the four land units. 
Wild cherry silvoarable systems became less profitable then arable systems, but remained more profitable than forestry systems on all 12 land units. In The Netherlands, poplar silvoarable systems became less profitable than arable systems and more profitable then forestry systems; the relative profitability of walnut silvoarable systems remained less profitable than the arable system, but more profitable than the forestry system.

Under scenarios 1 and 2 of the post-2005 grant regime, support for silvoarable systems was generally predicted to be more equitable in comparison with the pre-2005 grant regime. Hence, in Spain, the profitability of oak and stone pine silvoarable systems now frequently exceeded that of forestry systems and became only marginally less than that of arable systems on all 19 land units. Since oak and stone pine are important for their landscape value, the small difference between the equivalent annual values of the silvoarable and arable systems $\left(5-54 € \mathrm{ha}^{-1} \mathrm{a}^{-1}\right)$ represents the minimum level of additional support, perhaps as an agri-environment payment, required for silvoarable systems to become financially attractive to farmers. In France, the relative profitability of silvoarable, arable, and forestry systems for scenario 1 was similar to that in the pre-2005 grant regime, and increased marginally for scenario 2 , so that wild cherry silvoarable systems also became the most profitable systems in 6 of 12 land units. Walnut and poplar silvoarable systems continued to be the most profitable systems in all eight land units, in both scenarios 1 and 2, demonstrating the importance of using high value (walnut) or short rotation (poplar) trees in silvoarable systems. In The Netherlands, the relative profitability of silvoarable systems in comparison with the arable and forestry systems remained unchanged under both scenarios. The disadvantage of combining a long rotation with a low value for timber was illustrated by the use of walnut in The Netherlands. The importance of fully understanding all the costs associated with changing land use was illustrated by the high opportunity cost of losing land for slurry manure application, which made forestry relatively unprofitable under all the grant regimes.

\subsection{Farm-scale economics}

The effect of using silvoarable agroforestry was examined firstly in terms of its impact on the profitability of hypothetical farms and secondly as a means of establishing trees on farms. Under the pre-2005 grant regime in Spain, it was unprofitable to replace arable systems with silvoarable systems. This was due to low timber volume and value, and especially due to the lack of tree grants and the loss of arable area payments under the canopy-area based calculation. Under the post-2005 grant regime, replanting arable land with silvoarable systems still reduced farm profitability. By contrast, in France, establishing walnut and poplar silvoarable systems increased farm profitability under both the pre- and post-2005 grant regimes. Wild cherry silvoarable systems generally decreased farm profitability, due to low timber values and long rotations, except occasionally under scenario 2 of the post-2005 grant regime. In The Netherlands, introducing silvoarable systems in place of arable systems reduced farm profitability under both the preand the post-2005 grant regimes.
Under the pre-2005 grant regime in Spain, forestry generally provided farmers with a more attractive means of establishing trees on farms than silvoarable agroforestry, because of high levels of support for forestry systems. However, under the post-2005 grant regime, it was predicted that silvoarable agroforestry would become the most profitable means of establishing trees on farms in a substantial number of cases. In France and The Netherlands, silvoarable systems with walnut, wild cherry, and poplar provided the most profitable means of establishing trees on farms, irrespective of the grant regime used.

\section{Conclusions and recommendations}

Land equivalent ratios developed using Yield-SAFE predictions were consistently above one, indicating that growing trees and crops in silvoarable systems was more productive than growing them separately. Conditions that most favoured high land equivalent ratios appeared to include the use of relatively high tree-densities to make full use of available resources, the use of deciduous trees and autumn-planted crops to make complementary use of light, and high soil water availability to ensure that extra biomass production could be sustained. Conversely, low land equivalent ratios were associated with low tree density, evergreen trees, spring-planted crops, and low soil water availability.

The financial predictions made by Farm-SAFE indicated that silvoarable systems were most attractive where both components of the system were profitable as moncultures, since an unprofitable, or relatively unprofitable component, also reduced the profitability of the mixed system. In addition, the relative profitability of silvoarable systems tended to be maximised if the profitability of the forestry and arable systems was similar. Under the two scenarios proposed for the post-2005 grant regimes, it was predicted that silvoarable systems with walnut and poplar in France could provide a profitable alternative to arable or forestry systems. The importance of using high-value trees such as walnut or shortrotation trees such as poplar was illustrated by use of these trees in France. In Spain, it was predicted that holm oak and stone pine silvoarable systems would cause only small reductions in crop yields, relative to those in arable systems. Since these trees are of ecological and landscape importance for example, in areas of open woodlands (dehesas), rather than of production importance, additional support in the form of an agri-environment payment could be justified. A moderate annual amount would be sufficient to overcome income losses caused by yield reductions and encourage tree establishment for non-production benefits. In The Netherlands, the low value of timber and an opportunity cost, assumed because of the loss of arable land for slurry manure application, made both silvoarable and forestry systems relatively unattractive in comparison with arable systems.

A number of recommendations regarding further research can be made. Predictions are subject to uncertainty and this could be examined using sensitivity analysis or stochastic modelling. Certain baseline data should also be re-examined. For example, the recorded value of walnut timber in The Netherlands and France differed greatly, even though both 
countries are part of a free-trade zone. In The Netherlands, assumptions regarding slurry manure should be re-examined, since these greatly undermine the profitability of tree-based systems. In Spain, assumptions regarding beating-up, tree management and the availability of grants should be reassessed. Tree mortality is likely to be high due to difficult conditions, and pruning and thinning costs, whilst valid for traditional management of trees in dehesas, may not be valid for forestry and silvoarable systems, even if these are established in such areas. Finally, the post-2005 grant regime should be re-assessed, as the impact of the European Union's rural development strategy will become clearer in time.

\section{Acknowledgements}

This research was carried out as part of the SAFE (Silvoarable Agroforestry for Europe) collaborative research project. SAFE is funded by the EU under its Quality of Life programme, contract number QLK5-CT-2001-00560, and the support is gratefully acknowledged. We also acknowledge and are thankful for the involvement of Terry Thomas, Bob Bunce, Yvonne Reisner, Klaas Metselaar, and Martina Mayus at key stages in the project. Finally, we would like to thank the two anonymous reviewers of this paper, whose comments and suggestions have greatly helped us to improve it.

\section{REFERENCES}

Assemblée Permanente des Chambres d'Agriculture, 2005. Réseau d'observation des systèmes d'exploitation. http://paris.apca.chambagri.fr/apca/default.htm (accessed 5 May 2005).

Agricultural Economics Research Institute, 2005. Database of Agricultural Statistics for The Netherlands. http://www.lei.dlo.nl/uk/ (accessed 5 May 2005).

Boulet-Gercourt, B., 1997 Le merisier. Institut pour le Développement Forestier, 2ème édition, $128 \mathrm{pp}$.

Burgess, P.J., Graves, A.R., Metselaar, K., Stappers, R., Keesman, K., Palma, J., Mayus, M., van der Werf, W., 2004a. Description of Plot-SAFE Version 0.3. Unpublished document, 15 September 2004. Cranfield University: Cranfield, Bedfordshire, 52 pp. http://www.cranfield.ac.uk/sas/naturalresources/iessi/ projects/safe/ (accessed 1 November 2006).

Burgess, P.J., Incoll, L.D., Corry, D.T., Beaton, A., Hart, B.J., $2004 \mathrm{~b}$. Poplar (Populus spp.) growth and crop yields in a silvoarable experiment at three lowland sites in England. Agrofor. Syst. 63, 157-169.

Burgess, P.J., Seymour, I., Incoll, L.D., Corry, D.T., Hart, B., Beaton, A., 2000. The application of silvoarable agroforestry in the UK. Aspects Appl. Biol. 62, 269-276.

Centre Régional de la Propriété Forestière, 1997. Boiser une Terre Agricole, $28 \mathrm{pp}$.

Conrad, O., 2002. DiGeM - Software for Digital Terrain Analysis. http://www.geogr.unigoettingen.de/pg/saga/digem/index.html. (accessed 4 April 2005).

Dupraz, C., Lagacherie, M., Liagre, F., Boutland, A., 1995. Perspectives de diversification des exploitation agricoles de la région Midi-Pyrénées par l'agroforesterie. Rapport de fin d'études commandité par le Conseil Régional Midi-Pyrénées. Institute National de la Recherche Agronomique, Montpellier. Contract AIR3 CT92-0134, 253 pp.
Dupraz, C., 1998. Adequate design of control treatments in long term agroforestry experiments with multiple objectives. Agrofor. Syst. 43 (1/3), 35-48.

Dupraz, C., Newman, S., 1997. Temperate agroforestry: the European way. In: Gordon, A.M., Newman, S.M. (Eds.), Temperate Agroforestry Systems. CAB International, Wallingford, UK, pp. 181-236.

Dyack, B.J., Rollins, K., Gordon, A.M., 1999. A model to calculate ex ante the threshold value of interaction effects necessary for proposed intercropping projects to be feasible to the landowner and desirable to society. Agrofor. Syst. 44 (2/3), 197-214.

European Commission, 2004. Proposal for a Council Regulation on Support for Rural Development by the European Agricultural Fund for Rural Development (EAFRD). European Union Report No 2004.0161 (CNS), 68 pp.

European Commission, 2005. Farm Accountancy Data Network (FADN) Public Database. http://europa.eu.int/comm/ agriculture/rica/dwh/index_en.cfm (accessed 4 April 2005).

Faustmann, M., 1849. Berechnung des Wertes Waldboden sowie noch nicht haubare Holzbestände für die Waldwirfschaft besitzen. Allgemeine Forst und Jagd-Zeitung 25, 411-455.

Global Data Systems, 2005. Database of Historical Climate Data Compiled by Global Data Systems for the United States Department of Agriculture World Weather Board from World Meteorological Organisation climate reporting systems. http://hydrolab.arsusda.gov/nicks/nicks.htm (accessed 5 May 2005).

Graves, A.R., Matthews, R.B., Waldie, K., 2004. Low external input technologies for livelihood improvement in subsistence agriculture. Adv. Agron. 82, 473-555.

Graves, A.R., 2005. Bio-economic evaluation of agroforestry systems for Europe. Ph.D. Thesis. Cranfield University: Silsoe, Bedfordshire, $254 \mathrm{pp}$.

Graves, A.R., Burgess, P.J., Liagre, F., Terreaux, J.-P., Dupraz, C., 2005a. Development and use of a framework for characterising computer models of silvoarable economics. Agrofor. Syst. 65, 53-65.

Graves, A.R., Burgess, P.J., Liagre, F., Terreaux, J.-P., Borrel, T., Dupraz, C., et al., 2005b. Farm-SAFE: The development of a model of arable, forestry, and silvoarable economics. Unpublished document, 31 May 2005. Cranfield University: Cranfield, Bedfordshire, 52 pp. http://www.cranfield.ac.uk/ sas/naturalresources/iessi/projects/safe/ (accessed 1 November 2006).

Institut pour le Développement Forestier, 1997. Les noyer à bois, 3ème édition, $132 \mathrm{pp}$.

Mead, R., Willey, R.W., 1980. The concept of a "land equivalent ratio" and advantages in yields from intercropping. Expl. Agric. 16, 217-228.

Mercer, D.E., Miller, R.P., Nair, P.K.R., Latt, C.R., 1998. Socioeconomic research in agroforestry: progress, prospects, priorities. Agrofor. Syst. 38, 177-193.

Ministerie van Landbouw, Natuur en Voedselkwaliteit, 2004. Subsidieregeling Agrarisch Natuurbeheer. LASER vestging Roermond, Az Roermond, The Netherlands, $51 \mathrm{pp}$.

Ministry of Agriculture, Fisheries and Food, 1983. Definitions of Terms Used in Agricultural Business Management. MAFF Publication Booklet 2269, Alnwick, Northumberland, p. 39.

Montero and Cañella, 2000. Selvicultura de Pinus pinea L. Estado actual de los conociminetos en España. In: Simposio del pino piñonero (Pinus pinea, L.)., Valladolid, pp. 21-38.

Mücher, C.A., Bunce, R.G.H., Jongman, R.H.G., Klijn, J.A., Kooment, A.J.M., Metzger, M.J., Wascher, D.M., 2003. Identification and Characterisation of Environments and Landscapes in Europe. Alterra-rapport 832. Wageningen University, p. 119. 
Mücher, C.A., 2000. PELCOM Project. Final Report Submitted to the European Commission. Contract No ENV4-CT96-0315, 299 pp.

Nair, P.K.R., 1985. Classification of agroforestry systems. Agrofor. Syst. 3, 97-128.

Nix, J., 2001. Farm Management Pocketbook. Wye College Press, Ashford Kent, p. 244.

Ong, C.K., 1996. A framework for quantifying the various effects of tree-crop interactions. In: Ong, C.K., Huxley, P. (Eds.), Tree-Crop Interactions A Physiological Approach 1-23. CAB International, Wallingford.

Pulido, F.J., Campos, P., Montero, G., 2003. La gestión forestal de las dehesas. Historia, Ecológía, Selvicultura y economía. IPROCOR-Junta de Extremadura: Merida, Spain.

Sinclair, F.L., 1999. A general classification of agroforestry practice. Agrofor. Syst. 46, 161-180.

Souleres, G., 1992. les milieux de la populiculture. Institut pour le Développement Forestier, p. 310.

Thomas, T.H., 1991. A spreadsheet approach to the economic modelling of agroforestry systems. For. Ecol. Manage. 45, 207-235.

Thomas, T.H., Willis, R.W., 1997. Linking bio-economics to biophysical agroforestry models. Agrofor. Forum 8 (2), 40-42.

United States Department of Agriculture, 2005. CLIGEN Weather Generator. United States Department of Agriculture Agricultural Research Service and Unites States Forest Service
http://horizon.nserl.purdue.edu/Cligen/ (accessed 5 May 2005).

Van der Werf, W., Keesman, K., Burgess, P.J., Graves, A.R., Pilbeam, D., Incoll, L.D., Metselaar, K., Mayus, M., Stappers, R., Palma, J., Dupraz, C., van Keulen, H., 2007. Yield-SAFE: A parameter-sparse process-based dynamic model for predicting resource capture, growth and production in agroforestry systems. Ecol. Eng. 29, 419-433.

Van Genuchten, M.T., 1980. A closed-form equation for predicting the hydraulic conductivity of unsaturated soils. Soil Sci. Soc. Am. J. 44, 892-898.

Van Ittersum, M.K., Rabbinge, R., 1997. Concepts in production ecology for analysis and quantification of agricultural input-output combinations. Field Crops Res. 52 (3), 197-208.

Willis, R.W., Thomas, T.H., van Slycken, J., 1993. Poplar agroforestry: a re-evaluation of its economic potential on arable land in the United Kingdom. For. Ecol. Manage. 57, 85-97.

Wösten, J.H.M., Lilly, A., Nemes, A., Le Bas, C., 1999. Development and use of a database of hydraulic properties of European soils. Geoderma 90, 169-185.

Yagüe, S., 1994. Producción y selvicultura del pino piñonero (Pinus pinea L.) en la provincia de Avila. Montes 36, 45-51. 